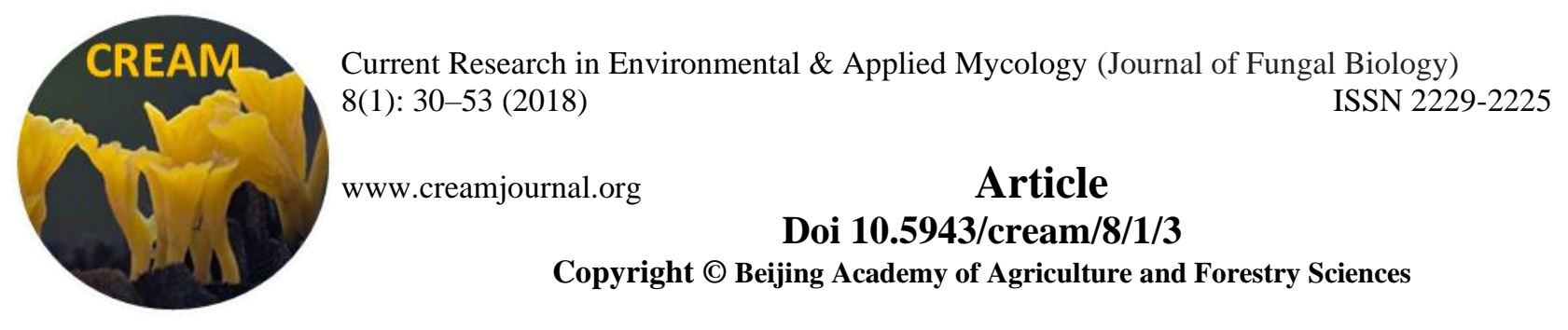

\title{
Notes on powdery mildews of the genus Erysiphe from Azerbaijan
}

\author{
Abasova LV ${ }^{1}$, Aghayeva DN', Takamatsu $\mathrm{S}^{2}$ \\ ${ }^{1}$ Institute of Botany, Azerbaijan National Academy of Sciences, Badamdar highway 40, Baku AZ1004, Azerbaijan \\ ${ }^{2}$ Graduate School of Bioresources, Mie University, 1577 Kurima-Machiya, Tsu 514-8507, Japan
}

Abasova LV, Aghayeva DN, Takamatsu S 2018 - Notes on powdery mildews of the genus Erysiphe from Azerbaijan. Current Research in Environmental \& Applied Mycology (Journal of Fungal Biology) 8(1), 30-53, Doi 10.5943/cream/8/1/3

\begin{abstract}
This study was performed to contribute towards an inventory of powdery mildews in Azerbaijan. Thirty-four powdery mildew samples on 18 host species were collected between 2014 and 2016 in different regions of Azerbaijan and examined by means of morphological and molecular methods. Consequently, 18 powdery mildew taxa have been identified. The morphological characteristics of these species are described and illustrated. Erysiphe arcuata, E. berberidis var. asiatica, E. corylacearum, E. quercicola, E. syringae-japonicae, and E. viciaeunijugae are new records of powdery mildews for Azerbaijan. In addition, Castanea sativa is a new host for E. quercicola, Lathyrus odorathus for E. viciae-unijugae, Berberis vulgaris for E. berberidis var. asiatica, and Carpinus orientalis for E. arcuata.
\end{abstract}

Key words - Erysiphaceae - molecular analysis - morphology - new host records - taxonomy

\section{Introduction}

Powdery mildews (Erysiphales, Erysiphaceae) are an important group of plant pathogenic fungi consisting of about 873 species of 17 genera (Braun \& Cook 2012), which infects ca 10,000 species of angiosperms worldwide and cause serious diseases on numerous economically important cultivated plants, such as cereals, crops, vegetables, flowers, fruit trees and ornamental plants, etc. (Amano 1986, Braun \& Cook 2012). All powdery mildew species are exclusively obligate biotrophs of plants, i.e., they feed on living plants. The taxonomy of powdery mildews on genus and species level has been significantly changed based on new molecular phylogenetic and new morphological approaches (Cook et. al. 1997, Braun \& Takamatsu 2000, Braun et al. 2002, Braun \& Cook 2012). For example, appendage morphology of chasmothecia that has long been regarded as an important morphological indicator to delimit powdery mildew genera is now rather considered a taxonomic trait to delimit species. Instead, morphological characteristics of asexual morphs like conidiogenesis (catenate or non-catenate conidia), fibrosin bodies, hyphal appressoria, conidial germ tubes, conidial surface structure, and parasitism (ectophytic or endophytic) turned out to be more important for the generic taxonomy of powdery mildews (Cook et. al. 1997, Mori et al. 2000, Cook \& Braun 2009). In this context, the three previous sections of the genus Erysiphe, viz., sects. Erysiphe, Golovinomyces, and Galeopsidis, were raised to the genus level (Braun \& Takamatsu 2000). The genera Microsphaera and Uncinula that have long been regarded as good genera were reduced to morphological, non-phylogenetic sections of Erysiphe (Braun \& Takamatsu 2000). Similarly, the genus Sphaerotheca was reduced to synonymy with Podosphaera and treated as morphological, non-phylogenetic section (Braun \& Takamatsu 2000). Revisions on species level 
have been conducted by several authors (Braun et al. 2001, 2006, Takamatsu et al. 2007, Braun \& Cook 2012, Siahaan et al. 2017).

Erysiphe is now the largest genus within the Erysiphaceae, which includes about 450 species belonging to five morphological sections. These sections differ from each other in the structures of the asexual morphs, especially in the appendage morphology, viz., mycelioid appendages in sect. Erysiphe (i); dichotomously branched appendages in sect. Microsphaera (ii); appendages with uncinate, circinate or helicoids tips in sect. Uncinula (iii); apical cells in the upper half in sect. Typhulochaeta (iv); single peridium cell layer and simple, mycelioid appendages in sect. Californiomyces (v). Basic characteristics of this genus are Pseudoidium-type conidiogenesis (i.e. producing conidia singly) and polyascal chasmothecia (Takamatsu et al. 2015a, b).

Investigations of powdery mildew fungi in Azerbaijan date back to the middle of the last century (Akhundov 1965a, b, 1979, Djafarov 1958, 1959, Guseynov 1985, Mekhtiyeva 1959). Identifications of preserved older herbarium specimens from Azerbaijan are based on the outdated taxonomic literature. However, the exploration of powdery mildews in Azerbaijan was largely neglected in the past 30 years, because other groups of fungi were in the focus of interest. The longterm aim of the present study is to contribute towards a better knowledge of the diversity of powdery mildews in Azerbaijan based on new taxonomic approaches, using herbarium specimens and additional fresh collections. In this study, we describe and illustrate Erysiphe species collected in Azerbaijan that have been identified by mean of combined analyses of morphological and molecular data.

\section{Materials \& Methods}

Samples used in this study were collected between 2014 and 2016 in Azerbaijan and deposited in Mycological Herbarium of Mie University (TSU-MUMH, Tsu, Japan), and Mycological Herbarium of Institute of Botany, Azerbaijan National Academy of Sciences (BAK Mycological Herbarium, Baku, Azerbaijan).

Morphological examinations: All dried herbarium samples were examined under an optical microscope according to the procedure outlined in Shin \& La (1993). To examine asexual morphs, small pieces of infected leaves were mounted in lactic acid on microscopic slides and gently boiled, then scrapped off from leaf surface. For observations of sexual structures, chasmothecia were stripped off from the leaf surface with a sterile needle, mounted on $3 \% \mathrm{NaOH}$ solution. Measurements were based on data from 30 samples for each structure. The original sizes of conidia were reconstructed with Bulmer's factor (Braun \& Cook 2012). Drawings were made by freehand from microscope observations. A scale bar is added to each picture and photos respectively.

Molecular and phylogenetic analyses: DNA extraction and sequencing of the 5'-end of the 28S rRNA gene (including domains D1 and D2) and rDNA ITS1-5.8S-ITS2 regions were carried out according to the procedure described in Meeboon \& Takamatsu (2015a). Whole cell DNA was extracted from mycelia or chasmothecia using the chelex method (Hirata \& Takamatsu 1996). ITS5 (5'-GGAAGTAAAAGTCGTAACAAGG-3')/ PM6 (5'-GYCRCYCYGTCGCGAG-3') or PM6m (5'-GGAGTTACTACGCGTAGAG-3') primers were used to amplify ITS region and PM3 (5'-GKGCTYTMCGCGTAGT-3'), PM9 (5'-GACCCTCCACCCGTG-3')/ and NLP2 (5'-GGTCCCAACAGCTATGCTCT-3') primers were used for 28S rRNA gene. Newly obtained nucleotide sequences were deposited in DNA Data Base of Japan (DDBJ) under the accession numbers LC270834-LC270838, LC270840-LC270851, LC270853-LC270863, and LC328320LC328326. These sequences were aligned with other sequences of the Erysiphaceae retrieved from DNA databases using MUSCLE in MEGA 7 (Edgar 2004, Kumar et al. 2016). The alignment was refined using MEGA7 and deposited in TreeBASE (http://www.treebase.org/) under the accession number S21704. Phylogenetic trees were obtained from the dataset by maximum parsimony method (MP) implemented in PAUP* 4.0b10 (Swafford 2002) and by maximum likelihood method (ML) using raxmlGUI (Silvestro \& Michalak 2012). The MP analysis was run with heuristic search option using the tree bisection reconnection (TBR) algorithm with 100 random sequence additions to find global optimum tree. The strengths of internal branches in resulting trees were tested with 
bootstrap analysis (BS) using 1000 replications with the step-wise addition option set as simple (Felsentein 1985). BS values higher than $70 \%$ are given. Tree scores, including tree length, consistency index (CI), retention index (RI), rescaled consistency index (RC) were calculated. The ML analysis was done using raxmlGUI, under a GTRGAMMA model. The BS supports and trees were obtained by running rapid bootstrap analysis of 1000 pseudo-replicates followed by a search for the tree with the highest likelihood.

\section{Results}

\section{Phylogenetic analyses}

Newly obtained 33 ITS and 28S rRNA gene sequences were aligned with 28 Erysiphe and two outgroup sequences retrieved from the DNA databases. Golovinomyces ambrosiae (AB769419) and Arthrocladiella mougeottii (AB329690) were used as outgroup based on the Mori et al. (2000). The alignment data matrix consists of 63 sequences and 1337 characters, of which $1033(77.3 \%)$ characters were constant and 78 (5.8\%) characters were variable, and $226(16.9 \%)$ characters were informative for parsimony analysis. As a result, ca $1.2 \times 10^{6}$ equally parsimonious trees with 537 steps were constructed by MP analysis. The best tree was chosen with KishinoHasegawa (Kishino \& Hasegawa 1989) and Shimodaira-Hasegawa (Shimodaira \& Hasegawa 1999) topology tests and a tree with the highest likelihood value is given in Fig. 1.

\section{Erysiphe sect. Erysiphe}

Erysiphe convolvuli DC., Fl. franç. 2: 274, 1805, var. convolvuli.

Fig. 2

Description - Mycelium amphigenous, caulicolous and foliicolous, effuse or forming irregular patches, often covering the whole leaf surface, persistent to evanescent. Hyphae hyaline, walls thin, smooth, 3-7 $\mu \mathrm{m}$ wide, hyphal appressoria lobed, solitary or in opposite pairs. Conidiophores arising from top of the mother cells, erect, 71-116(-124) $\mu \mathrm{m}$ long, foot-cells cylindrical, straight, 23-41 $\times 5-9 \mu \mathrm{m}$, followed by two shorter or cells of the same length. Conidia formed singly, cylindrical to ellipsoid-cylindrical, 40-60(-62) $\times 14-19(-21) \mu \mathrm{m}$, length/width ratio 2.3-3.7. Chasmothecia scattered to gregarious, 103-153(-166) $\mu \mathrm{m}$ diam., appendages $10-40$, in the lower half of ascomata, mycelioid, simple or sometimes 1-2 times irregularly branched, interlaced with each other, walls hyaline, thin, smooth to rough, sometimes lower half pigmented from yellowish to brownish, septate, 4-8 $\mu \mathrm{m}$ wide. Asci 4-8, sessile or short-stalked, broad ellipsoid-ovoid, saccate, 46-68 × (27-)30-40 $\mu \mathrm{m}, 3-5$-spored. Ascopores ellipsoid-ovoid, (14-)17$22 \times 9-13 \mu \mathrm{m}$, colorless.

Specimens examined - On Convolvulus arvensis L. (Convolvulaceae), Lokbatan, Baku, N

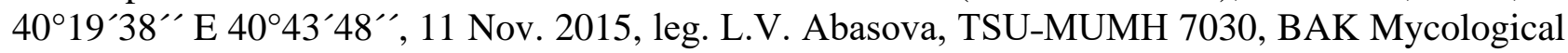
Herbarium No 10055, DDBJ ID no: LC270857 (ITS) and LC328321 (28S rRNA gene); Masall, N 39²’3” E 48 39'56", 30 Jul. 2016, leg. L.V. Abasova, TSU-MUMH 7048, BAK Mycological Herbarium No 10073, DDBJ ID no: LC328325 (ITS); On Calystegia sepium (L.) R. Br.

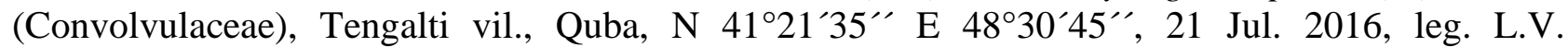
Abasova, TSU-MUMH 7001, BAK Mycological Herbarium No 10026, DDBJ ID no: LC270835 (ITS and 28S rRNA gene).

Notes - Three specimens on Convolvulus and Calystegia were examined with molecular and morphological methods. Erysiphe convolvuli is the only powdery mildew species of the genus Erysiphe on plants of the family Convolvulaceae. According to the "Manual of Erysiphales" (Braun \& Cook 2012), this species has three varieties, of which var. convolvuli and calystegia are distributed in Azerbaijan (Akhundov 1965b, Mekhtiyeva 1959). Host ranges of these varieties are mainly confined to Convolvulus and Calystegia, respectively. However, var. convolvuli sometimes occurs also on Calystegia species. The main morphological difference between these varieties lies in the number of ascospores per ascus, viz. 3-5(-6) in var. convolvuli and (3-)5-6 in var. calystegia (Braun \& Cook 2012). Sequence results of these specimens were in agreement with available $E$. 
ITS + 28S rDNA

63 sequences

1337 characters

$\mathrm{CI}=0.7207$

$\mathrm{RI}=0.8866$

$\mathrm{RC}=0.6390$

E alphitoides ex Quercus petrea AB257435

E.alphitoides ex Quercus macranthera MUMH7008

76/80 E. alphitoides ex Quercus robur AB292710

E. alphitoides ex Quercus serrata AB292695

E. euonymicola ex Euonymus japonicus MUMH6999

E. euonymicola ex Euonymus japonicus MUMH7012

94 E. euonymicola ex Euonymus japonicus AB250228

E. euonymicola ex Euonymus japonicus AB250229

100/99 E. quercicola ex Castanea sativa MUMH7028

E. quercicola ex Castanea sativa MUMH7029

E. quercicola ex Quercus crispula AB292691

- E. berberidicola ex Berberis vulgaris LC009951

E. berberidis ex Berberis vulgaris LC010057

100/99 E. berberidis ex Berberis vulgaris MUMH7022

E. berberidis ex Berberis vulgaris MUMH7005

E. multappendicis ex Berberis vulgaris AB104520

E. euonymi ex Euonymus europeae LC010050

83/- E. trifoliorum ex Trifolium arvense LC009955

83/96 E. trifoliorum ex Trifolium pratense MUMH7031

E. trifoliorum ex Trifolium pratense MUMH7046

E. trifoliorum ex Medicago sativa MUMH7038

E. trifoliorum ex Medicago sp. FJ378877

- E. convolvuli ex Calystegia sepium MUMH7001

E. convolvuli ex Convolvulus arvensis MUMH7030

- E. convolvuli ex Ipomoea aquatica KJ885178

E. convolvuli ex Convolvulus arvensis MUMH7048

85/93 E. cruciferarum ex Brassica juncea KM260718

E. cruciferarum ex Brassica rapa EU140958

89/91 E. cruciferarum ex Brassica juncea MUMH7034

98/90 E. heraclei ex Torilis arvensis MUMH7041

92/71 97/92 E. heraclei ex Conium maculatum LC010021

E. polygoni ex Polygonum aviculare MUMH7036

E. polygoni ex Polygonum arenastrum AF011307

E. viciae unijugae ex Vicia angustifolia LC009962

E. viciae-unijugae ex Vicia bifolia LC009977

E. viciae-unijugae ex Lathyrus odorathus MUMH7040

E. pisi ex Lathyrus latifolium AF011306

E. syringae ex Syringa vulgaris MUMH7018

E. syringae ex Syringa vulgaris LC015612

E. syringae ex Syringa vulgaris MUMH7019

$100 / 100$ E platani ex Platanus orientalis JQ365943

E. platani ex Platanus orientalis MUMH7006

E. platani ex Platanus orientalis MUMH7050

99/96 E E corylacearum ex Corylus heterophylla KR048061

E. corylacearum ex Corylus avellana MUMH7047

E. corylacearum ex Corylus sieboldiana LC009928

98/98 E. syringae-japonicae ex Syringa vulgaris AB295458

E. syringae-japonicae ex Syringa vulgaris MUMH7017

E. syringae-japonicae ex Syringa vulgaris MUMH7013

E. syringae-japonicae ex Syringa vulgaris MUMH7015

$89 / 96$

E syringae-japonicae ex Syringa vulgaris MUMH7016

E. syringae-japonicae ex Syringa vulgaris MUMH7020

E. syringae-japonicae ex Syringa vulgaris MUMH7014

E. syringae-japonicae ex Syringa vulgaris MUMH7021

$100 / 100$ E. arcuata ex Carpinus orinetalis MUMH7010

E. arcuata ex Carpinus betulus AB252459

E. arcuata ex Carpinus betulus AB252463

E. necator ex Vitis vinifera MUMH7026

E. necator ex Vitis vinifera LC028996

E. necator ex Vitis vinifera MUMH7027

Arthrocladiella mougeotii AB329690

Golovinomyces ambrosiae AB769419

- 5 changes

Fig. 1 - Phylogenetic analysis of the genus Erysiphe inferred from ITS + 28S rRNA gene sequences constructed by maximum parsimony (MP) method. Bootstrap values $(\geq 70 \%)$ in MP and maximum likelihood analysis (ML) are shown on the branches. Sequences determined in this study were highlighted by blue. 
convolvuli sequences. The allocation of the E. convolvuli specimen on $C$. sepium from Azerbaijan (TSU-MUMH 7001) to one of the varieties of this species was not possible owing to immature asci and unavailable reference sequences from authentic material of var. calystegia. On the other hand, specimens on Convolvulus could be easily identified as E. convolvuli var. convolvuli based on the 3-5-spored asci. As shown in Fig. 1, E. convolvuli formed a distinct monophyletic group and was supported by strong BS values (100\% in both, MP and ML analyses). Two nucleotide sequences of the specimens on Convolvulus were identical to each other, whereas there were 3 nucleotide differences (99.3\%) in 28S rRNA gene between the specimens on Calystegia and on Convolvulus.

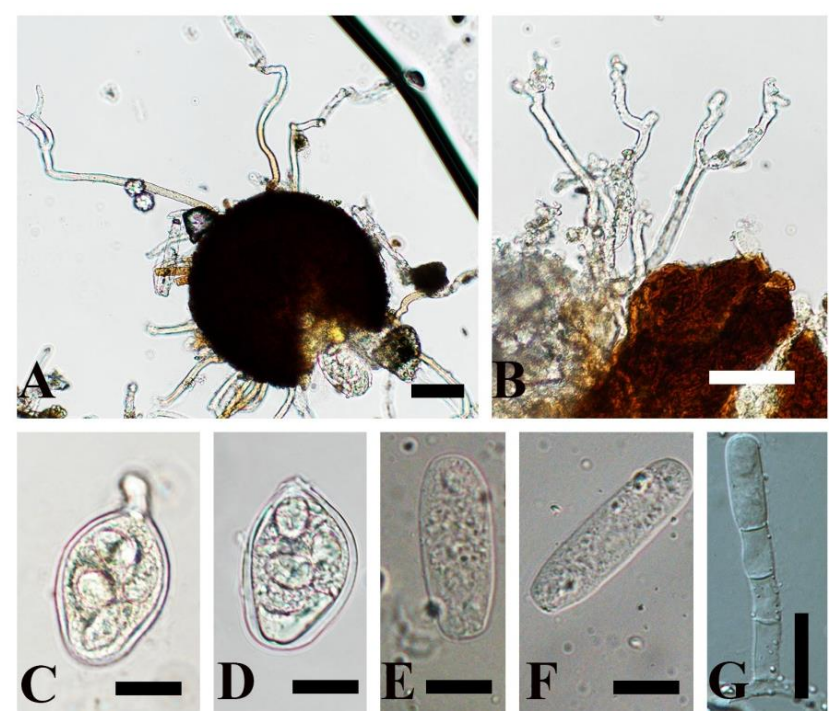

Fig. 2 - Erysiphe convolvuli var. convolvuli on Convolvulus arvensis. A Chasmothecium. B Appendages. C, D Asci and ascospores (TSU-MUMH 7030). E, F Conidia. G Conidiophore (TSUMUMH 7048). Bars $=20 \mu \mathrm{m}$.

Erysiphe cruciferarum Opiz ex L.Junell, Sv. Bot. Tidskr. 61(1): 217, 1967.

Fig. 3

Description - Mycelium amphigenous, on stems and leaves, effuse or in patches, white, thin, persistent to evanescent. Hyphae 4-7 $\mu \mathrm{m}$ wide, thin-walled, smooth, hyaline, hyphal appressoria slightly lobed, solitary or in opposite pairs. Conidiophores arising from the top of mother cell, (75)88-118 $\mu \mathrm{m}$ long. Foot-cells flexuous to straight, cylindrical, $25-57 \times 6-9 \mu \mathrm{m}$, followed by $1-2$ shorter cells or one longer cell. Conidia formed singly, ellipsoid-doliiform to sometimes cylindrical-doliiform, (24-)27-37 × 14-19 $\mu \mathrm{m}$, length/width ratio (1.4-)1.5-2.2. Germ tubes terminal, short or moderately long, simply lobed.

Specimen examined - On Brassica juncea L. (Brassicaceae), Baku, 19 May 2016, leg. L.V. Abasova, TSU-MUMH 7034, BAK Mycological Herbarium No 10059, DDBJ ID no: LC270859 (ITS and 28S rRNA gene).

Notes - Only one powdery mildew species, E. cruciferarum, is known on Brassica spp. and morphological characteristics of this species are consistent with our specimen (Braun \& Cook 2012). Nucleotide sequences of ITS and 28S rRNA gene were identical to the sequences of $E$. cruciferarum on Alyssum allissoides (KU672365) and A. hirsutum (KU672346) in GenBank. A sequence determined in this study was combined with two sequences of E. cruciferarum on Brassica retrieved from GenBank. These three sequences were grouped together with 85/93\% BS values, but there are three nucleotide substitutions between our sequence and the sequences retrieved from GenBank in ITS region (Fig. 1). Our specimen was identified as E. cruciferarum based on these results. This species is already known from Azerbaijan on this plant (Akhundov 1965b). 

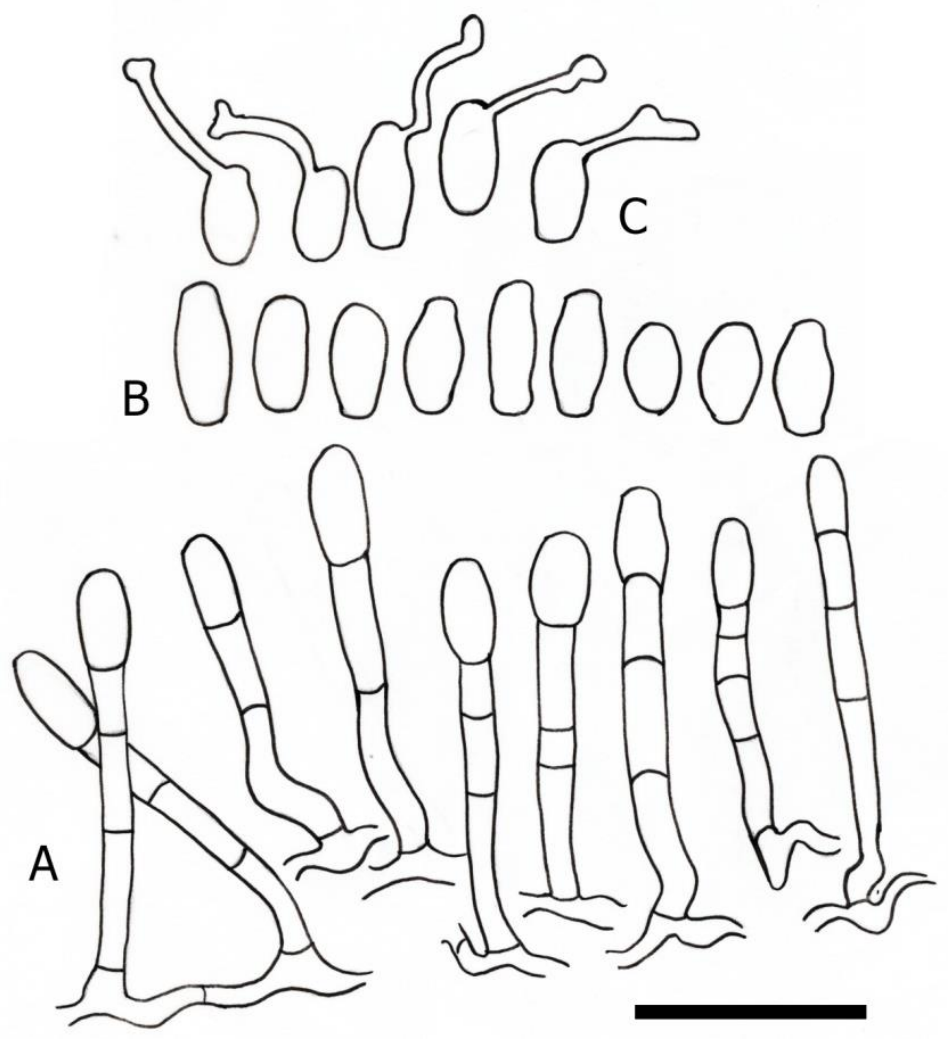

Fig. 3 - Erysiphe cruciferarum on Brassica juncea (TSU-MUMH 7034). A Conidiophores. B Conidia. $\mathrm{C}$ conidial germ tubes and appressoria. $\mathrm{Bar}=60 \mu \mathrm{m}$.

Erysiphe heraclei DC., Fl. franç. 6: 107, 1815.

Fig. 4

Description - Mycelium amphigenous, on stems, inflorescences and leaves, effuse or in patches, persistent. Chasmothecia scattered to gregarious, (78-)81-135 $\mu \mathrm{m}$ diam., appendage number variable, few to numerous, in the lower half of ascomata, mycelioid, simple or sometimes irregularly branched, interlaced with each other, 5-8 $\mu \mathrm{m}$ wide, $0.5-1.5(-2)$ times as long as the chasmothecial diam., septate, walls thin, smooth, pigmented, but paler towards the apex. Asci (2)3-5, broad ellipsoid-ovoid, clavate to saccate, 44-66 $\times(27-) 30-40 \mu \mathrm{m}$, sessile or short-stalked, (2-)3-5-spored. Ascospores ellipsoid-ovoid, (15-)17-21 × (8-)9-12 $\mu \mathrm{m}$, colorless.

Specimen examined - On Torilis arvensis (Huds.) Link. (Apiaceae), Tengaltı vil., Quba, N

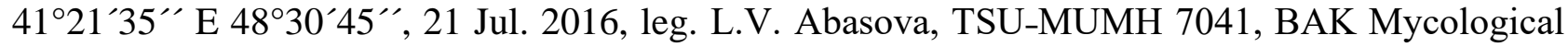
Herbarium No 10066, DDBJ ID no: LC270862 (ITS and 28S rRNA gene).

Notes - Erysiphe heraclei, the only powdery mildew species of the genus Erysiphe on numerous hosts of the family Apiaceae, is common and widespread (Braun \& Cook 2012). Newly obtained sequences of ITS and 28S rRNA gene from our specimens were completely identical to the sequences of E. heraclei on Osmorhiza chilensis (LC010004) and Conium maculatum (LC010021). A sequence from our specimen was combined with a sequence of E. heraclei retrieved from GenBank. These sequences formed a distinct group with high BS values supported by 98/90\% in MP and ML analyses (Fig. 1). Characteristics of sexual morphs of our specimen were in good agreement with the description of E. heraclei in Braun \& Cook (2012). The identification was based on molecular and morphological analyses. This species has already been recorded from Azerbaijan (Mekhtiyeva 1959, Akhundov 1965b, Kljuchova 1965, Akhundov \& Aghayeva 1978). 


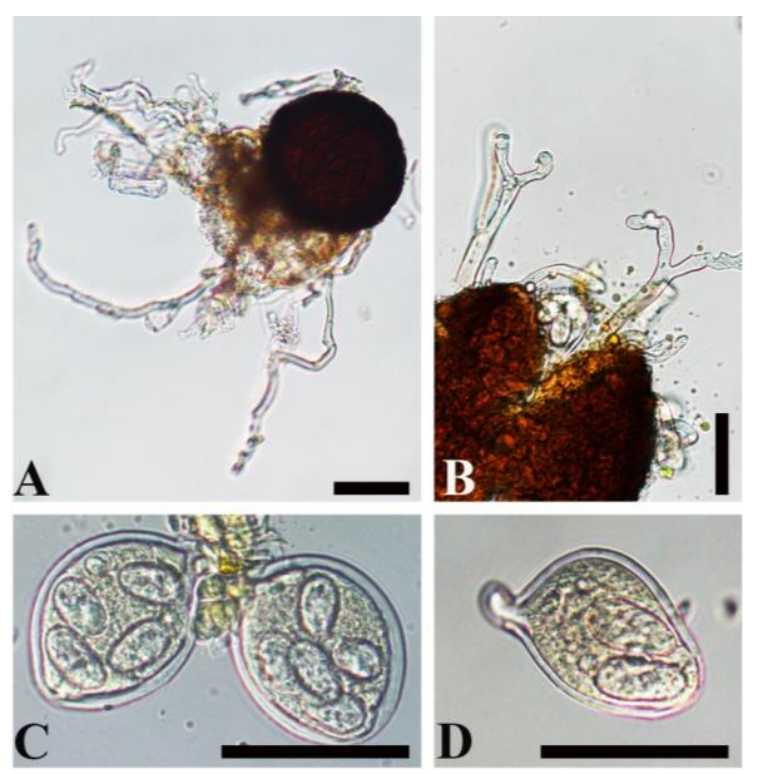

Fig. 4 - Erysiphe heraclei on Torilis arvensis (TSU-MUMH 7041). A Chasmothecium. B Chasmothecium and appendages. C, D Asci and ascospores. Bars $=40 \mu \mathrm{m}$.

Erysiphe polygoni DC., Fl. franc. 2: 273, 1805.

Fig. 5

Description - Mycelium amphigenous, white, dense, effuse, often covering the entire leaf surface, persistent. Hyphae thin-walled, hyaline, 4-7(-8) $\mu \mathrm{m}$ wide, hyphal appressoria lobed, solitary or in opposite pairs, 7-13 $\mu \mathrm{m}$ wide. Conidiophores arising from the top of mother cell, 94$120 \mu \mathrm{m}$ long. Foot-cells cylindrical, flexuous to straight, $(22-) 26-45 \times(5-) 6-8 \mu \mathrm{m}$, followed by $1-$ 2 shorter cells or one cell of the same length. Conidia formed singly, cylindrical, rarely ellipsoid, 36-51 × 13-22 $\mu \mathrm{m}$, length/width ratio 1.9-3(-3.4).
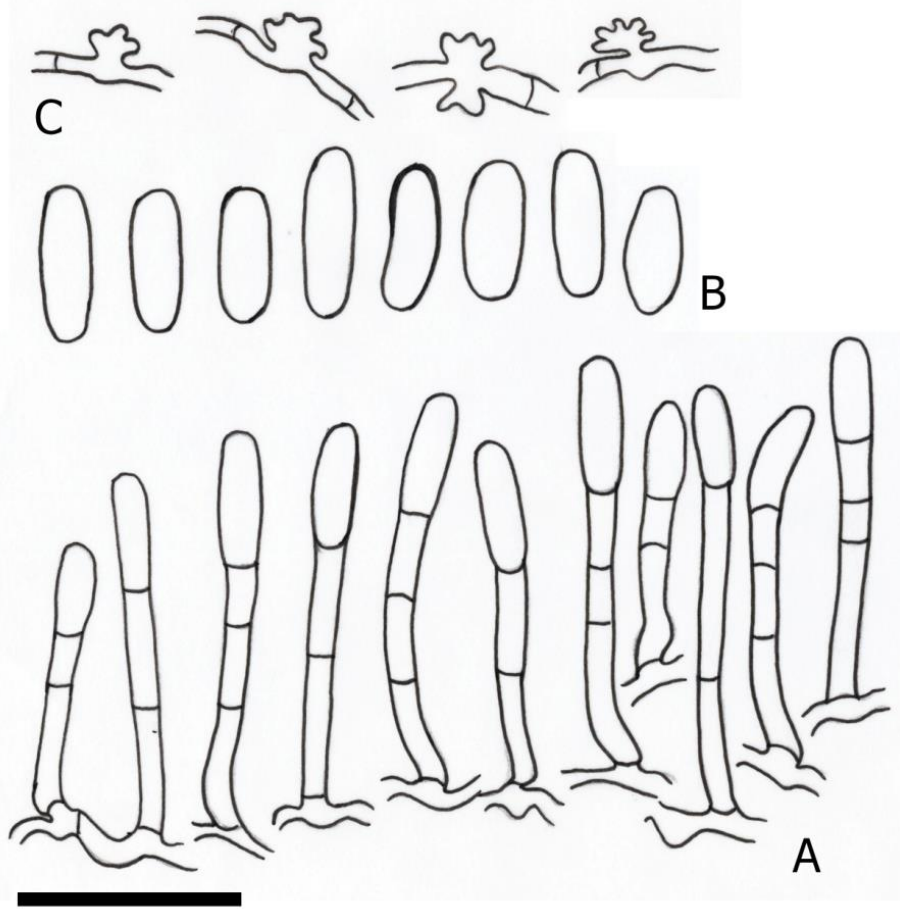

Fig. 5 - Erysiphe polygoni on Polygonum aviculare (TSU-MUMH 7036). A Conidiophores. B Conidia. $\mathrm{C}$ hyphal appressoria. $\mathrm{Bar}=50 \mu \mathrm{m}$. 
Specimens examined - On Polygonum aviculare L. (Polygonaceae), Baku, 09 Jun. 2016, leg. L.V. Abasova, TSU-MUMH 7036, BAK Mycological Herbarium No 10061, DDBJ ID no:

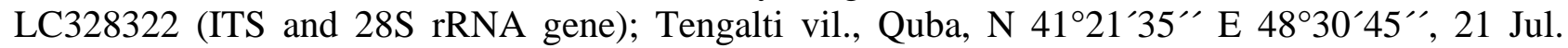
2016, leg. L.V. Abasova, TSU-MUMH 7045, BAK Mycological Herbarium No 10070, DDBJ ID no: LC328323 (ITS and 28S rRNA gene).

Notes - Erysiphe polygoni is common and widespread on Polygonum spp. (Braun \& Cook 2012). The asexual morph of this fungus is characterized by having long conidiophores (up to 180 $\mu \mathrm{m}$ long) and large, cylindrical conidia with high $1 / \mathrm{w}$ ratio (1.9-3.1), which is consistent with the characteristics of our specimens. The sequence of ITS rDNA region of our specimen was $99 \%$ identical (1 base difference) to E. polygoni on Homocladium platycloidium (KX098506), but the sequence of $28 \mathrm{~S}$ rRNA gene was $99 \%$ identical to sequences of the closely allied species Erysiphe betae and E. buhrii in GenBank (sequences of 28S rRNA gene for E. polygoni are not available in GenBank). Two sequences obtained from our specimens were combined with a retrieved sequence of E. polygoni. These sequences formed a distinct clade supported by 100/98\% BS values, respectively in MP and ML analyses (Fig. 1).

Erysiphe viciae-unijugae (Homma) U.Braun, Feddes Repert. 92(7-8): 499, 1981.

Fig. 6

Description - Mycelium amphigenous, thin, effuse or in patches, on leaves and stems, fruits, evanescent to persistent. Chasmothecia gregarious to scattered, (92-)98-149 $\mu \mathrm{m}$ diam., appendages in the lower half of ascomata, mycelioid, often irregularly branched, numerous, distinctly pigmented from base to tip, or paler towards the apex, of the same length as the chasmothecial diam. or shorter, interlaced with each other, 4-8 $\mu \mathrm{m}$ wide, aseptate or rarely 1-2 septa in the lower half, walls smooth to rough, hyaline. Asci (3-)4-6, ellipsoid-ovoid, saccate, sessile or short-stalked,

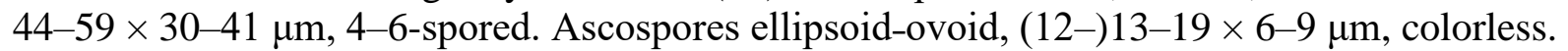

Specimens examined - On Lathyrus odoratus L. (Fabaceae), Tengalti vil., Quba, N

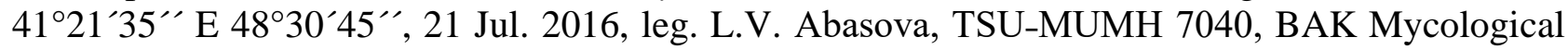
Herbarium No 10065, DDBJ ID no: LC270861 (ITS and 28S rRNA gene).
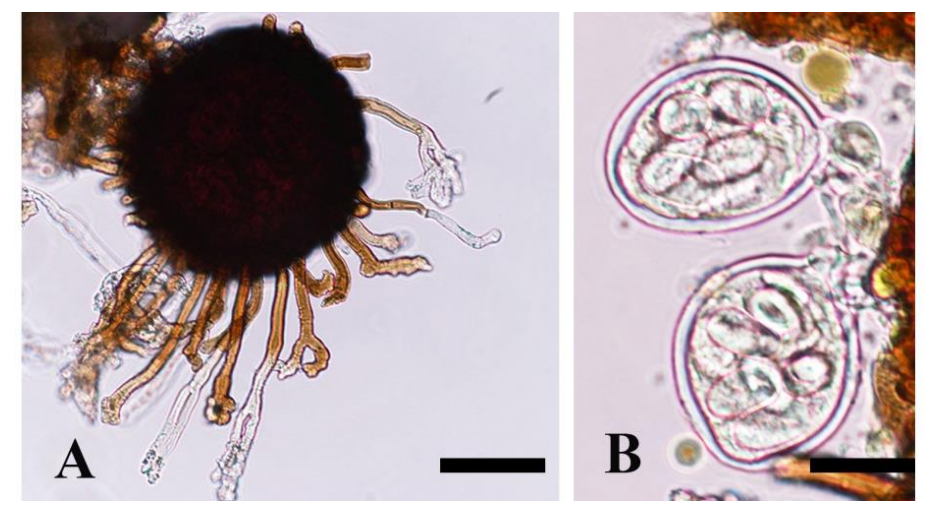

Fig. 6 - Erysiphe viciae-unijugae on Lathyrus odoratus (TSU-MUMH 7040). A Chasmothecium. B Asci and ascospores. Bars $=30 \mu \mathrm{m}$.

Notes - Erysiphe pisi, E. viciae-unijugae, E. lathyricola, and E. trifoliorum are known on Lathyrus spp. worldwide (Braun \& Cook 2012). Erysiphe lathyricola, belonging to sect. Microsphaera, differs from our specimen in having dichotomously branched appendages. The length of appendages in E. trifoliorum is 2-6 times as long as chasmothecial diam., which differs from our specimen which has shorter appendages. The number of ascospores per ascus, and the length and branching of appendages showed that our specimen is morphologically more similar to E. viciae-unijugae, rather than to E. pisi. The appendages are often branched and the length is shorter in E. viciae-unijugae compared to E. pisi. A sequence of $28 \mathrm{~S}$ rRNA gene of our sample was identical to E. viciae-unijugae on Vicia sp. (LC010029), but the ITS sequence was 99\% identical to $E$. pisi on Vicia faba (JN228214). We compared this "E. pisi" sequence with another sequence of $E$. 
pisi (AF011306) and sequences of E. viciae-unijugae, and found that sequence JN228214 is completely identical to E. viciae-unijugae. We thus suggest that the species of sequence JN228214 was misidentified. Nucleotide similarity between E. pisi and E. viciae-unijugae is $97.7 \%$ in ITS region, whereas the sequence from our specimen has $99 \%$ similarity with E. viciae-unijugae. A sequence from our specimen was combined with two sequences of E. viciae-unijugae and a sequence of $E$. pisi, retrieved from GenBank. In the phylogenetic analysis the sequence from our specimen grouped with the sequences of E. viciae-unijugae (Fig. 1). According to the morphological similarity of sexual structures of our specimen with E. viciae-unijugae and results of molecular-phylogenetic analysis, our specimen was identified as E. viciae-unijugae. This fungus is a new record for Azerbaijan and Lathyrus odorathus is a new host plant for E. viciae-unijugae.

\section{Erysiphe sect. Microsphaera}

Erysiphe alphitoides (Griff. \& Maubl.) U. Braun \& S. Takam., Schlechtendalia 4: 5, 2000. Fig. 7

Description - Mycelium amphigenous, often epiphyllous, persistent, but evanescent on the lower side of leaves, white to grayish, effuse or in patches, or covering the whole leaf surface, infected leaves disfigured and distorted. Hyphae 3-6 $\mu \mathrm{m}$ wide, hyphal appressoria lobed, solitary or in opposite pairs. Conidiophores arising from upper surface of the mother cell, or slightly lateral, erect, 50-102 $\mu \mathrm{m}$ long. Foot-cells cylindrical, straight to curved, 20-33 $\times 4-7 \mu \mathrm{m}$, followed by 1-3 shorter cells, or sometimes by cells of the same length. Conidia formed singly, ellipsoid-ovoid, doliiform, rarely subcylindrical, $25-42 \times(12-) 13-21 \mu \mathrm{m}$, length/width ratio 1.7-2.3.

Specimen examined - On Quercus macranthera Fisch. \& C.A. Mey. ex Hohen. (Fagaceae),

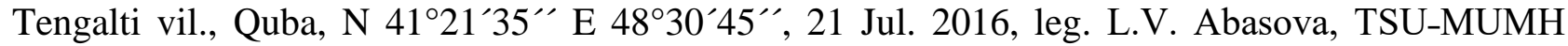
7008, BAK Mycological Herbarium No 10033, DDBJ ID no: LC270838 (ITS and 28S rRNA gene).
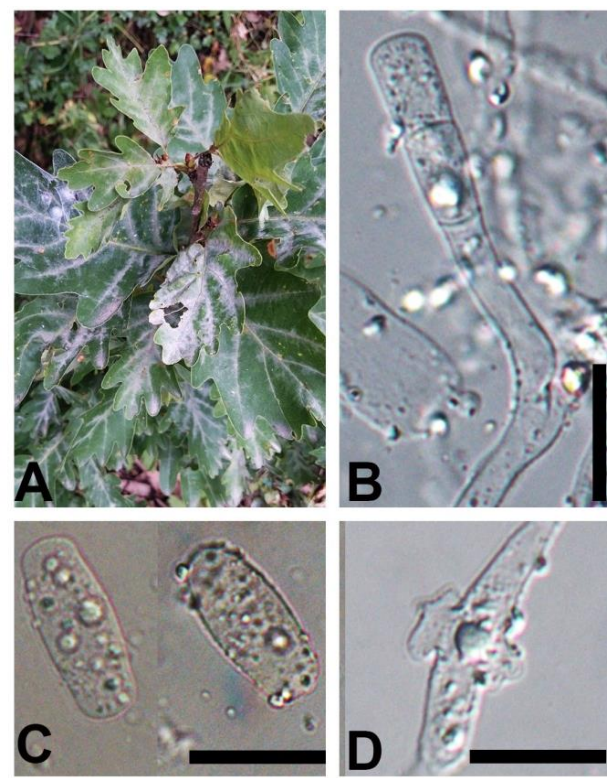

Fig. 7 - Erysiphe alphitoides on Quercus macranthera (TSU-MUMH 7008). A Disease symptom on infected leaves. B Conidiophore. C Conidia. D Hyphal appressoria. Bars $=30 \mu \mathrm{m}$.

Notes - Erysiphe abbreviata (Peck.) U. Braun \& S. Takam., E. alphitoides, E. epigena S. Takam. \& U. Braun, E. hypogena S. Takam. \& U. Braun, E. hypophylla (Nevod.) U. Braun \& Cunnington, and E. quercicola S. Takam. \& U. Braun are powdery mildew species of sect. Microsphaera on Quercus spp. (Braun \& Cook 2012). The asexual morph found in Azerbaijan on Quercus macranthera agree well with characters of the mycelium, conidiophores and conidia of $E$. alphitoides described in Braun \& Cook (2012). The conidiophore length of E. quercicola (up to 90 
$\mu \mathrm{m})$ is shorter than conidiophores of our specimen. Other morphological characteristics of the asexual structures of E. quercicola are very similar to our specimen. Therefore, molecular methods have been applied in addition to morphological examinations in order to confirm the identification of our specimen as E. alphitoides. Nucleotide sequences of 28S rRNA gene and ITS were identical to E. alphitoides sequences deposited in GenBank. A newly obtained sequence from our specimen was combined with three other sequences of E. alphitoides retrieved from GenBank. These sequences formed a group together with $76 / 80 \%$ BS values and placed at the most derived position in the phylogentic tree (Fig. 1). Thus, our specimen was confirmed as E. alphitoides based on combined molecular and morphological results.

Erysiphe berberidis DC. var. asiatica (U. Braun) U. Braun \& S. Takam., Schlechtendalia 4: 6, 2000.

Fig. 8

Description - Mycelium amphigenous, mostly epyphyllous, on stems, fruits and leaves, effuse or in patches, thin, white, evanescent to persistent. Hyphae 3-5 $\mu \mathrm{m}$ wide, hyphal appressoria nipple-shaped to lobed, solitary or in opposite pairs. Conidiophores arising from top of the mother cell, up to $90 \mu \mathrm{m}$ long. Foot-cells cylindrical, straight to flexuous, 13-25 $\times 5-7 \mu \mathrm{m}$, followed by $1-$ $2(-3)$ shorter cells. Conidia formed singly, cylindrical to ellipsoid, 27-40 $\times 9-14 \mu \mathrm{m}$, length/width ratio 2.5-3.6. Chasmothecia scattered to gregarious, (76-)80-126 $\mu \mathrm{m}$ diam., appendages 4-20, equatorial, stiff, straight to flexuous, about $70-130 \times 7-10 \mu \mathrm{m}$, i.e., about as long as the chasmothecial diam., pigmented at the base, 0-1 septate, walls rough, thick towards the base and thin above, apices 3-5 times regularly and densely dichotomously branched, primary and sometimes secondary branches short or somewhat elongated, tips straight to recurved. Asci 4-10, ellipsoid-ovoid, saccate, (34-)40-57 × 26-40 $\mu \mathrm{m}$, sessile or short-stalked, 2-5-spored, but mainly 3-4-spored. Ascospores ellipsoid-ovoid, 12-22 × 8-12 $\mu \mathrm{m}$, colorless.

Specimens examined - On Berberis vulgaris L. (Berberidaceae), Baku, Botanical garden, 12 Jul. 2016, leg. L.V. Abasova, TSU-MUMH 7005, BAK Mycological Herbarium No 10030, DDBJ ID no: LC270836 (ITS and 28S rRNA gene); Baku, Botanical garden, 20 Oct. 2016, leg. L.V. Abasova, TSU-MUMH 7022, BAK Mycological Herbarium No 10047, DDBJ ID no: LC270851 (ITS and 28S rRNA gene).
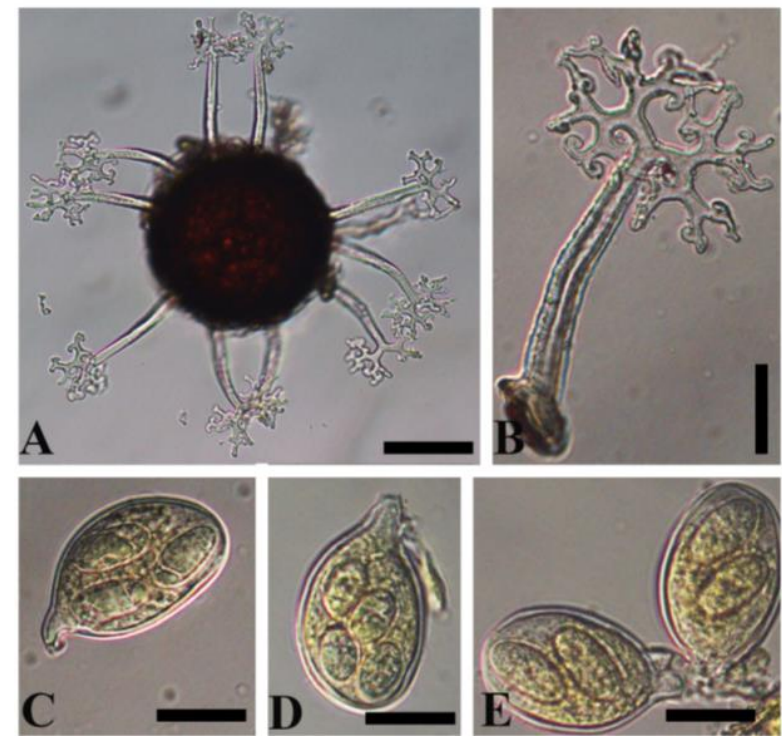

Fig. 8 - Erysiphe berberidis var. asiatica on Berberis vulgaris (TSU-MUMH 7022). A Chasmothecium. B Appendage. C, D, E Asci and ascospores. Bars $=30 \mu \mathrm{m}$.

Notes - Several Erysiphe species belonging to sect. Microsphaera have been recorded on Berberis species, such as E. berberidicola (F.L. Tai) U. Braun \& S. Takam., E. berberidis, E. dimorpha (Y.N. Yu \& Z.Y. Zhao) U. Braun \& S. Takam., E. golovinii (Domashova) U. Braun \& S. 
Takam., E. multappendicis (Z.Y. Zhao \& Y.N. Yu) U. Braun \& S. Takam., and E. thaxteri (Havryl. \& U. Braun) U. Braun \& S. Takam. (Braun \& Cook 2012). The morphological characteristics of the specimens collected in Azerbaijan, especially the sexual morph of our specimen, are identical to E. berberidis var. asiatica (Braun \& Cook 2012), except for the ultimate tips of the branched apices of the appendages which are straight to recurve. E. berberidis var. berberidis differs in having longer appendages, 1-3, mostly 1.5-2 times as long as the chasmothecial diam., with more irregularly branched appendages and consistently straight tips. ITS sequences of our specimens were identical to the sequences of E. multappendicis (AB104520) and E. berberidis (LC010057) in GenBank. Two new sequences determined in this study were combined with sequences of $E$. multappendicis, E. berberidis and E. berberidicola retrieved from GenBank. In total, these five sequences grouped together with 100/99\% BS values (Fig. 1). The sequence from our specimen differed in five bases in ITS region (99.1\%) from the sequence of E. berberidicola. Our specimens were identified as E. berberidis var. asiatica based on morphological results. It seems that ITS sequences are not sufficient for a clear genetic differentiation within this group of allied species of Erysiphe sect. Microsphaera on Berberis spp., which is not uncommon for plant pathogenic ascomycetes. E. berberidis var. berberidis was known from Azerbaijan so far (Djafarov 1958). Thus, E. berberidis var. asiatica is a new powdery mildew record for the country and Berberis vulgaris is a new host for this fungus.

Erysiphe corylacearum U. Braun \& S. Takam., Schlechtendalia 8: 33, 2002.

Fig. 9

Description - Mycelium amphigenous, forming dense, irregular patches, persistent. Hyphae 3-7 $\mu \mathrm{m}$ wide, septate, branched, hyphal appressoria lobed, solitary. Conidia formed singly, ellipsoid-ovoid to doliiform, (25-)27-38 $\times 14-21 \mu \mathrm{m}$, length/width ratio $1.4-1.9(-2)$. Chasmothecia scattered to gregarious, (79-)81-101 $\mu \mathrm{m}$ diam., appendages (3-)5-11, equatorial, straight, 4-5 times dichotomously branched, tips recurved, 73-110 $\times 6-8(-11) \mu \mathrm{m}$, walls rough, pigmented and enlarged towards the base, but thin above, aseptate, or single septum at the base. Asci (3-)4-5, broad ellipsoid-ovoid, subglobose, 37-50 × (27-)29-39 $\mu \mathrm{m},(4-) 5-8$-spored, stalked or sessile. Ascospores ellipsoid-ovoid, 13-18 ×8-11 $\mu \mathrm{m}$, colorless.

Specimen examined - On Corylus avellana L. (Betulaceae), Tengalti vil., Quba, N

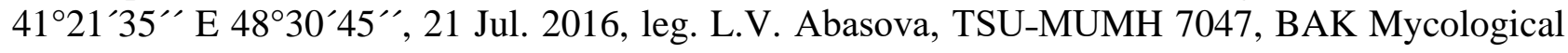
Herbarium No 10072, DDBJ ID no: LC270863 (ITS and 28S rRNA gene).
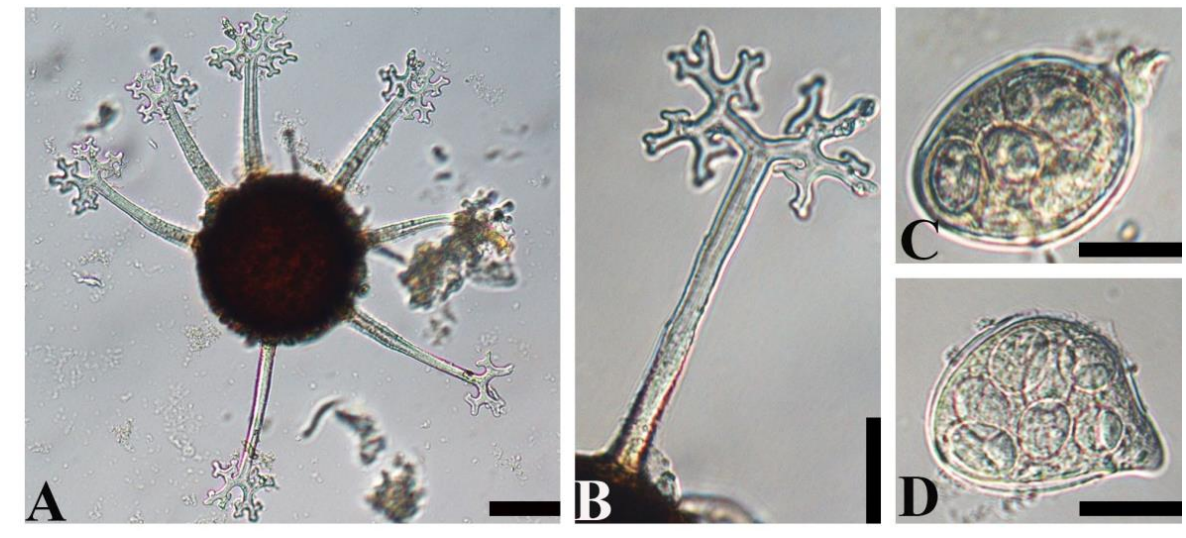

Fig. 9 - Erysiphe corylacearum on Corylus avellana (TSU-MUMH 7047). A Chasmothecium. B Appendage. C, D Asci and ascospores. Bars $=30 \mu \mathrm{m}$.

Notes - Phyllactinia guttata (Wallr: Fr.) Lév. is a common powdery mildew pathogen on Corylus spp. in Azerbaijan so far (Akhundov 1965a, Akhundov \& Aghayeva 1978). However, our morphological examination revealed that the specimen examined belongs to a species of Erysiphe sect. Microsphaera, since the sexual morph is characterized by having dichotomously branched appendages and polyascal chasmothecia. Erysiphe corylacearum, E. corylicola U. Braun \& S. 
Takam., E. corylopsidis Shiroja \& S. Takam., and E. verruculosa (Y.N. Yu \& Y.Q. Lai) U. Braun \& S. Takam are powdery mildew species belonging to Erysiphe sect. Microsphaera on Corylus spp. (Braun \& Cook 2012). The sexual morph of our specimen is morphologically identical to $E$. corylacearum, a species known on Corylus spp. in Asia and North America (Braun \& Cook 2012). Sequences of ITS and 28S rRNA gene were 99\% identical (only 1 base difference) to $E$. corylacearum on Corylus heterophylla Fisch. ex Trautv. (KR048061) and C. sieboldiana Blume (LC009928). A newly obtained sequence was aligned with two other sequences of E. corylacearum retrieved from DNA data base. These sequences formed a distinct group with 99/96\% BS values, respectively, in MP and ML analyses. Based on these results, the present specimen was identified as E. corylacearum. Erysiphe corylacearum on C. avellana has recently been recorded from Turkey (Sezer et al. 2017). This is the first record of this species from Azerbaijan.

Erysiphe euonymicola U. Braun, in Braun \& Cook (2012: 461).

Fig. 10

Description - Mycelium amphigenous, effuse or in patches, dense, white, persistent, confluent. Hyphae straight to flexuous, cells about 4-6 $\mu \mathrm{m}$ wide, hyphal appressoria lobed, solitary or in opposite pairs. Conidiophores arising from top of the mother cell, and centrally, (37-)40-70 $\mu \mathrm{m}$ long, foot-cells cylindrical, straight to flexuous, (13-)17-24 $\times 4-7 \mu \mathrm{m}$, followed by 1-2 shorter cells or a cell of about the same length. Conidia formed singly, ellipsoid-cylindrical, (23-)25-35 $\times$ 11-14 $\mu \mathrm{m}$, length/width ratio 1.8-2.9. Germ tubes terminal or subterminal, showing longitubus pattern, conidial appressoria lobed.

Specimens examined - On Euonymus japonicus Thunb. (Celastraceae), Isti-su resort, Masall1, N 39²’3” E 48³9'56”, 30 Jul. 2016, leg. L.V. Abasova, TSU-MUMH 6999, BAK Mycological Herbarium No 10024, DDBJ ID no: LC270834 (ITS and 28S rRNA gene); Baku, 02 Jul. 2015, leg. L.V. Abasova, TSU-MUMH 7012, BAK Mycological Herbarium No 10037, DDBJ ID no: LC270841 (ITS and 28S rRNA gene).

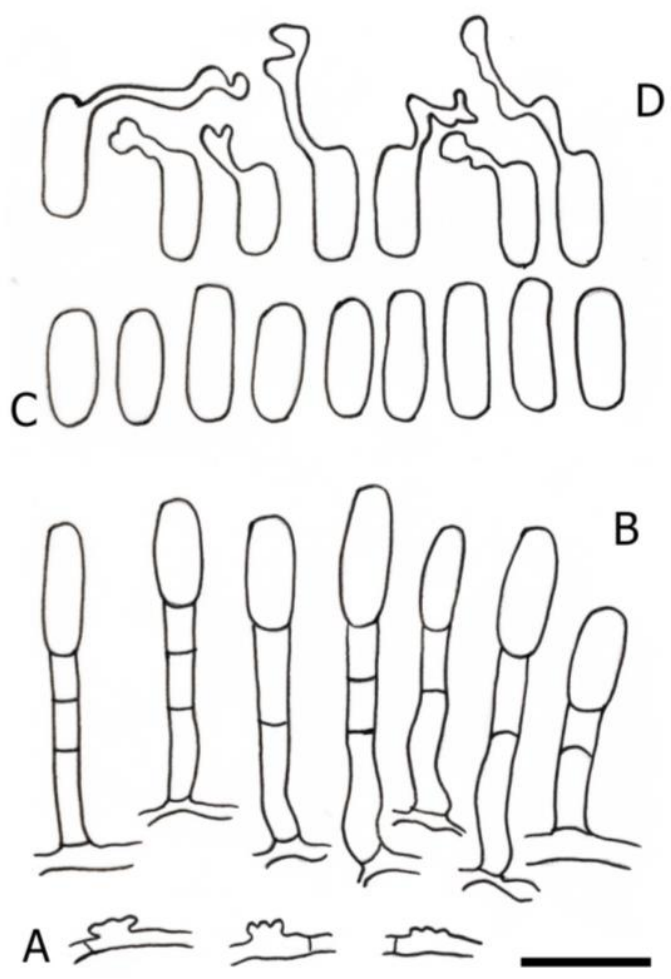

Fig. 10 - Erysiphe euonymicola on Euonymus japonicus (TSU-MUMH 7012). A Hyphal appressoria. B Conidiophores. C Conidia. D conidial germ tubes. Bar $=30 \mu \mathrm{m}$. 
Notes - Euonymus species are infected by E. euonymi DC., E. euonymicola, E. lianyugangensis (S.R.Yu) U. Braun \& S. Takam., E. mayumi (Y. Nomura) U. Braun \& S. Takam., and E. pseudopusilla U. Braun \& S. Takam. Of these species only E. euonymicola and E. lianyungangensis have been found on E. japonicus. Morphological differences to our specimen are to be found in larger conidia in E. lianyungangensis $(26.5-45 \times 11.5-17 \mu \mathrm{m})$ and in E. mayumi $(28-50 \times 15-22 \mu \mathrm{m})$, and longer conidiophores in E. mayumi (up to $100 \mu \mathrm{m})$. Erysiphe pseudopusilla differs from our specimens by its slightly oblong conidia $(30-40 \times 13-17 \mu \mathrm{m})$. Asexual morphs of E. euonymi and E. euonymicola are more similar to each other (Braun \& Cook 2012). As in our specimens only asexual morphs are formed, it is difficult to identify the species concerned. Therefore, the powdery mildews on Euonymus japonicus were subjected to phylogenetic analyses. Sequences of ITS and 28S rRNA gene were identical to E. euonymicola. Two newly obtained sequences from our specimens were combined with two sequences of $E$. euonymicola and formed a group within the E. alphitoides clade (Fig. 1). Based on these results, the specimens from Azerbaijan were identified as E. euonymicola.

Erysiphe platani (Howe) U. Braun \& S. Takam., Schlechtendalia 4: 12, 2000.

Fig. 11

Description - Mycelium amphigenous, on petioles, inflorescences and leaves, dense, white, effuse or in patches, sometimes covering the whole leaf surface, persistent, leaves often disfigured or distorted. Hyphae 3-6 $\mu \mathrm{m}$ wide, hyphal appressoria lobed, solitary. Conidiophores arising from top of the mother cells, centrally, very long, (126-)150-270 $\mu \mathrm{m}$, width increasing towards the apex. Foot-cells straight to flexuous, cylindrical, (27-)35-100 × 4-7 $\mu \mathrm{m}$, followed by one long and 1-2
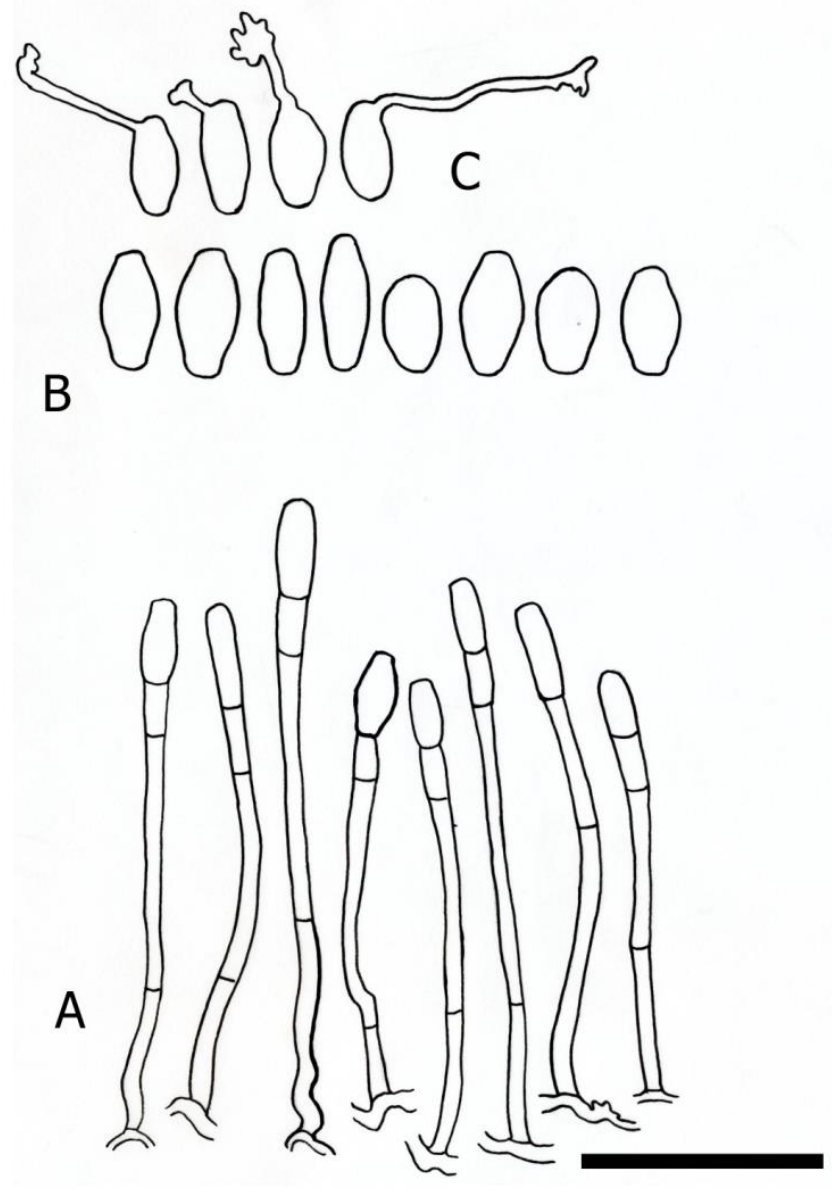

Fig. 11 - Erysiphe platani on Platanus orientalis (TSU-MUMH 7006). A Conidiophores. B Conidia. $\mathrm{C}$ conidial germ tube and appressoria. $\mathrm{Bar}=100 \mu \mathrm{m}$. 
shorter cells. Conidia formed singly, ellipsoid-ovoid to doliiform, 34-44(-46) $\times 17-22(-24) \mu \mathrm{m}$, length/width ratio (1.4-)1.7-2.3. Germ tubes mostly terminal or so, showing longtibus pattern.

Specimens examined - On Platanus orientalis L. (Platanaceae), Lokbatan, Baku, N

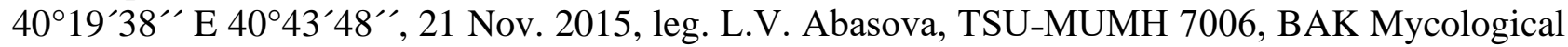
Herbarium No 10031, DDBJ ID no: LC270837 (ITS and 28S rRNA gene); Masall1, N 39²’3" E 48³9'56", 30 Jul. 2016, L.V. Abasova, TSU-MUMH 7050, BAK Mycological Herbarium No 10075, DDBJ ID no: LC328326 (ITS).

Notes - Erysiphe platani is the sole powdery mildew species found on hosts belonging to the family Platanaceae (Braun \& Cook 2012). Sequences from our samples were identical to sequences of E. platani (AB926022) in GenBank. Two newly determined sequences were combined with a sequence of $E$. platani (JQ365943) retrieved from GenBank. These three sequences formed a distinct clade with 100/100\% BS values, in MP and ML analyses, respectively. The morphology of asexual structures in our specimens was in good agreement with the description of E. platani (Braun \& Cook 2012). Thus, the two specimens from Azerbaijan were identified as E. platani based on molecular and morphological results. Although collections of samples were carried out from early summer until late autumn, no sexual stage of this fungus was found in Azerbaijan. We also revised samples kept in the Mycological Herbarium of Institute of Botany, but could not find any chasmothecia present in the specimens concerned, confirming that E. platani does not produce chasmothecia in Azerbaijan. This fungus was first described by Howe (1874) as Microsphaera platani on Platanus occidentalis L. from USA. This fungus expanded its geographic distribution to South America, Asia, Europe and South Africa (Braun \& Cook 2012). In Japan, E. platani was found only in its asexual stage as well. Recently, sexual morphs have been described for E. platani in Japan (Meeboon \& Takamatsu 2015b).

Erysiphe quercicola S. Takam. \& U. Braun, Mycol. Res. 111: 819, 2007.

Fig. 12

Description - Mycelium amphigenous, mainly epiphyllous, inconspicuous on the lower side of leaves, persistent to evanescent, white to somewhat grayish, thin, forming irregular patches. Hyphae septate, hyaline, 4-7 $\mu \mathrm{m}$ wide, thin walled, hyphal appressoria well-developed, lobed, solitary or in opposite pairs. Conidiophores arising from the top of mother cells, centrally, erect, (33-)44-87 $\mu \mathrm{m}$ long. Foot-cells cylindrical, straight to flexuous, thin below and thick above, 15-31 $\times(4-) 5-8 \mu \mathrm{m}$, followed by 1-2 shorter cells. Conidia formed singly, ellipsoid-obovoid to doliiform, apex rounded, base subtruncate, $25-37(-42) \times 18-22 \mu \mathrm{m}$, length/width ratio 1.3-2.

Specimens examined - On Castanea sativa L. (Fagaceae), Bash Kungut vil., Shaki, 6 Jun. 2015, leg. L.V. Abasova and D.N. Aghayeva, TSU-MUMH 7028, BAK Mycological Herbarium No 10053, DDBJ ID no: LC270855 (ITS and 28S rRNA gene); Gabala, Zaraghan vil., 05 Jun. 2015, leg. L.V. Abasova and D.N. Aghayeva, TSU-MUMH 7029, BAK Mycological Herbarium No 10054, DDBJ ID no: LC270856 (ITS and 28S rRNA gene).

Notes - Erysiphe seguinii (Y.N.Yu \& Y.Q. Lai) U. Braun \& S. Takam., E. castaneigena U. Braun \& Cunnington, E. castaneae U. Braun and E. alphitoides are species known to attack Castanea spp. (Braun \& Cook 2012). The asexual morph of the Chinese endemic species E. seguinii is still unknown. Erysiphe castaneigena differs from our specimens in having straight footcells, larger conidia [30-45 $\times 16-22 \mu \mathrm{m}]$ and a larger length/width ratio (1.6-2.8). Erysiphe castanea is distinguished from our samples by its smaller conidia [28-35 $\times 14-18 \mu \mathrm{m}]$. The length of conidiophores of E. alphitoides is longer [95(-200) $\mu \mathrm{m}]$ than in our specimens. Morphologically, none of these species were in agreement with our specimens. However, ITS and 28S rRNA gene sequences of our specimens were completely identical to the sequences of E. quercicola (AB193607, AB292694) deposited in GenBank. Morphological characteristics of asexual structures in our specimens are identical to the description of E. quercicola in Braun \& Cook (2012). So far, Erysiphe alphitoides has been considered the sole powdery mildew on $C$. sativa in Azerbaijan. Because E. quercicola belongs to E. alphitoides s. lat. (Takamatsu et al. 2007), records of "E. alphitoides" from Azerbaijan may be misidentifications, i.e., they might rather refer to $E$. 
quercicola. Castanea sativa is a new host for Erysiphe quercicola worldwide. In addition, this species is a new record for Azerbaijan.

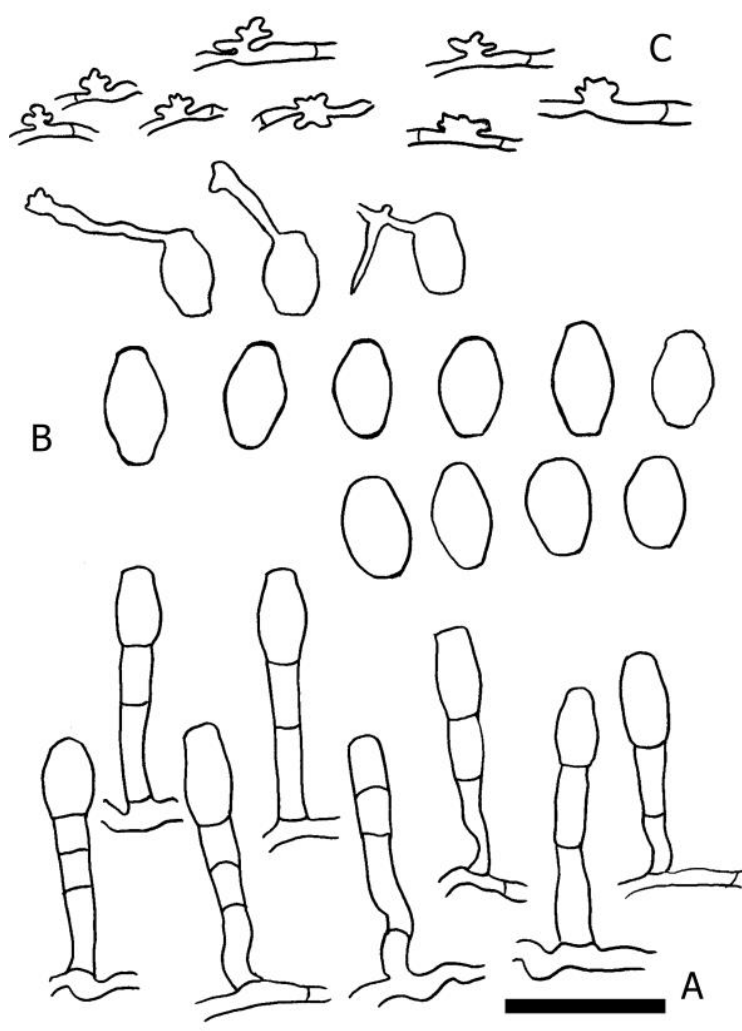

Fig. 12 - Erysiphe quercicola on Castanea sativa (TSU-MUMH 7028). A Conidiophores. B Conidia and conidial germ tubes. $\mathrm{C}$ hyphal appressoria. $\mathrm{Bar}=50 \mu \mathrm{m}$.

Erysiphe syringae-japonicae (U. Braun) U. Braun \& S. Takam., Schlechtendalia 4: 14, 2000.

Fig. 13

Description - Mycelium amphigenous, effuse or in patches, sometimes covering the whole leaf surface, evanescent to persistent. Hyphae 3-5 $\mu \mathrm{m}$ wide, hyphal appressoria lobed, solitary or in opposite pairs. Chasmothecia scattered to gregarious, (73-)86-120 $\mu \mathrm{m}$ diam., appendages 3-10, equatorial, stiff, straight, $(71-) 77-120 \times 6-9(-10) \mu \mathrm{m}$, aseptate or with a single septum at the base, pigmented from base up to the middle of the appendages or, sometimes pigmented up to the branched apex, only apices hyaline, stalk thick-walled towards the base, walls smooth or rough, apices 4-6 times dichotomously branched, tips recurved. Asci 3-6, broad ellipsoid-ovoid, saccate, 36-58 $\times 32-50 \mu \mathrm{m}$, sessile or short-stalked, 5-8-spored. Ascospores ellipsoid-ovoid, subglobose, 14-20 × 8-14 $\mu \mathrm{m}$, colorless.

Specimens examined - On Syringa vulgaris L. (Oleaceae), Tengalti vil., Quba, N 41 $21^{\prime} 35^{\prime \prime}$ E 48 30'45"', 19 Jul. 2016, leg. L.V. Abasova, TSU-MUMH 7013, BAK Mycological Herbarium No 10038, DDBJ ID no: LC270842 (ITS) and LC328320 (28S rRNA gene); TSU-MUMH 7014, BAK Mycological Herbarium No 10039, DDBJ ID no: LC270843 (ITS); TSU-MUMH 7015, BAK Mycological Herbarium No 10040, DDBJ ID no: LC270844 (ITS); TSU-MUMH 7016, BAK Mycological Herbarium No 10041, DDBJ ID no: LC270845 (ITS); TSU-MUMH 7017, BAK

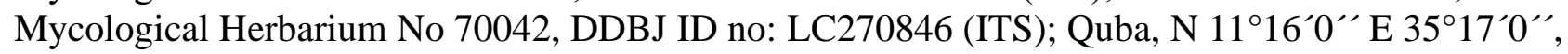
15 Aug. 2016, leg. D.N. Aghayeva, TSU-MUMH 7020, BAK Mycological Herbarium No 10045, DDBJ ID no: LC270849 (ITS and 28S rRNA gene); TSU-MUMH 7021, MH 10046, DDBJ ID no: LC270850 (ITS).

Notes - Syringa vulgaris (lilac) is cultivated as an ornamental plant worldwide. Reexaminations of herbarium samples kept in Mycological Herbarium of Institute of Botany revealed that E. syringae was recorded as the only powdery mildew pathogen of lilac in Azerbaijan so far 
and only occurred as asexual morphs. Surprisingly, fully developed chasmothecia of a powdery mildew on lilac leaves were observed on new collections from Azerbaijan. Erysiphe syringae and E. syringae-japonicae are two powdery mildew species on lilac species of sect. Microsphaera. According to Seko et al. (2008, 2011), E. syringae occurs as asexual stage in Europe, whereas the Asian E. syringae-japonicae expanded its distribution into Europe and usually produces chasmothecia. A recent study revealed that the North American E. syringae was the first lilac powdery mildew in Europe, but now the two Erysiphe species can coexist even on the same leaves (Takamatsu et. al. 2016). DNA was extracted separately from chasmothecia and mycelia, and nucleotide sequences were determined for each of them. DNA sequences from mycelia and chasmothecia were identical to each other and $100 \%$ identical to E. syringae-japonicae (AB295458; LC010006) in GenBank, confirming that a single powdery mildew species was involved. Morphological differences between E. syringae and E. syringae-japonicae lie in the pigmentation of chasmothecial appendages, and the number of ascospores per ascus (Seko et al. 2011). Hence, shorter chasmothecial appendages, pigmented up to the middle or even apex of the stalk, and 5-8-spored asci in the present specimens are in favour of E. syringae-japonicae (Seko et al. 2008, 2011). Seven sequences newly determined from our specimens were combined with a sequence retrieved from GenBank in this study. These sequences formed a distinct clade, which was supported by $89 / 96 \%$ BS values in MP and ML analyses, respectively (Fig. 1). This is the first record of Erysiphe syringae-japonicae from Azerbaijan.
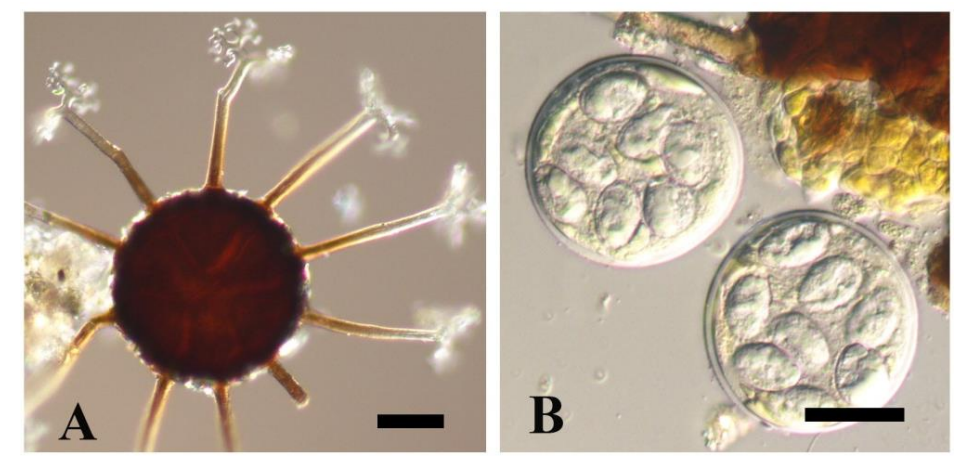

Fig. 13 - Erysiphe syringae-japonica on Syringa vulgaris (TSU-MUMH 7020). A Chasmothecium. B Asci and ascospores. Bars $=30 \mu \mathrm{m}$.

Erysiphe syringae Schwein., Trans. Amer. Philos. Soc. 4: 270, 1834.

Fig. 14

Description - Mycelium amphigenous, white to grayish, forming irregular patches or effuse, sometimes covering the whole leaf surface, persistent to rarely evanescent, mostly evanescent on the lower leaf surface. Hyphae 3-5 $\mu \mathrm{m}$ wide, straight to flexuous-sinuous, hyphal appressoria lobed, solitary or in opposite pairs, 6-9 $\mu \mathrm{m}$ wide. Conidiophores arise from the upper surface of mother cell, centrally or towards one end, erect, $47-67 \mu \mathrm{m}$ long. Foot-cells cylindrical, straight to flexuous-sinuous, 20-29(-32) $\times 5-7 \mu \mathrm{m}$, followed by 1-2(-3) shorter cells. Conidia formed singly, ellipsoid to cylindrical, 25-39 $\times(9-) 10-16 \mu \mathrm{m}$, length/width ratio 2.1-3.3.

Specimens examined - On Syringa vulgaris L. (Oleaceae), Botanical garden, Baku, 19 Sep. 2016, leg. L.V. Abasova, TSU-MUMH 7018, BAK Mycological Herbarium No 10043, DDBJ ID no: LC270847 (ITS and 28S rRNA gene); TSU-MUMH 7019, BAK Mycological Herbarium No 10044, DDBJ ID no: LC270848 (ITS).

Notes - Two specimens of asexual morphs were collected in Baku, Azerbaijan. Obtained sequences were identical to the sequences of Erysiphe syringae (LC015612; AB571048) in GenBank. Two sequences generated in this study were used in the present phylogenetic analysis combined with a sequence of E. syringae (LC015612) retrieved from GenBank (Fig. 1). Asexual morphs of these two specimens were consistent with the description of E. syringae in Braun \& Cook (2012). Based on these results, our specimen was identified as E. syringae. The geographic origin of E. syringae is North America, and chasmothecial formation is common there, whilst it is 
rare in Europe (Seko et al. 2008, 2011, Takamatsu et al. 2016). A revision of herbarium samples kept in mycological herbarium of Institute of Botany and morphological examinations of new collections showed that this species occurred only in its asexual stage in Azerbaijan.
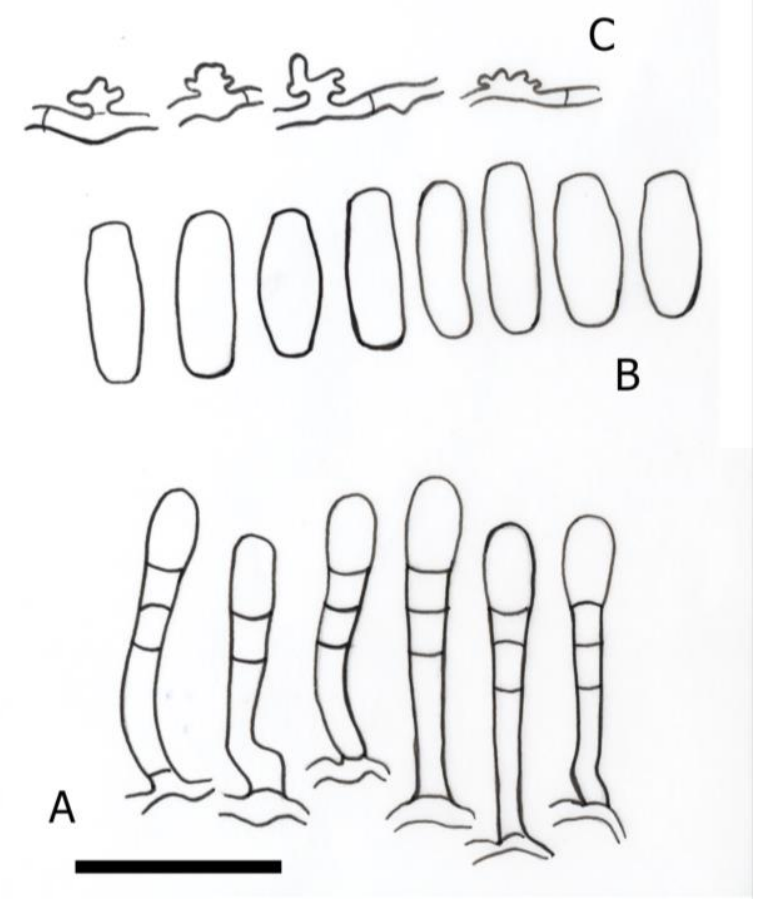

Fig. 14 - Erysiphe syringae on Syringa vulgaris (TSU-MUMH 7018). A Conidiophores. B Conidia. $\mathrm{C}$ hyphal appressoria. Bar $=30 \mu \mathrm{m}$

Erysiphe trifoliorum (Wallr.) U. Braun, Mycotaxon 112: 175, 2010.

Fig. 15

Description - Mycelium amphigenous, effuse or in patches, often covering the entire leaf surface, persistent to rarely evanescent. Hyphae 4-7 $\mu \mathrm{m}$ wide, hyphal appressoria lobed, solitary or in opposite pairs. Conidiophores arising from the top of mother cell, centrally, 66-101(-124) $\mu \mathrm{m}$ long, foot-cells cylindrical, flexuous-sinuous to straight, $24-42 \times 6-10 \mu \mathrm{m}$, followed by 1-2 shorter cells or cell of about the same length. Conidia formed singly, doliiform to ellipsoid-cylindrical, 32$45 \times 15-21 \mu \mathrm{m}$, length/width ratio 1.6-2.6. Chasmothecia scattered to gregarious, (89-)98-129 $\mu \mathrm{m}$ diam., appendages 15-30, flexuous, or sinuous, 2-4 times longer than the chasmothecial diam., pigmented when mature, yellowish to brown, paler towards to the apex, walls smooth to rough, thin or thick throughout, interlaced with each other, septate, apices simple or sometimes loosely dichotomously branched. Asci 3-8, broad ellipsoid-ovoid, saccate, clavate, (42-)45-68 × 34-54 $\mu \mathrm{m}$, short-stalked or sessile, (2-)3-5(-6)-spored. Ascospores ellipsoid-ovoid, 13-18 $\times(8-) 9-12$ $\mu \mathrm{m}$, colorless.

Specimens examined - On Trifolium pratense L. (Fabaceae), Khacmaz vil., Okhuz, N $41^{\circ} 28^{\prime} 2.92^{\prime \prime}$ E 48 48'53.16”, 04 Jul. 2015, leg. L.V. Abasova, TSU-MUMH 7031, BAK Mycological Herbarium No 10056, DDBJ ID no: LC270858 (ITS and 28S rRNA gene); Tengalti

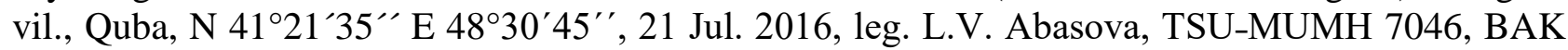
Mycological Herbarium No 10071, DDBJ ID no: LC328324 (ITS and 28S rRNA gene).

Notes - Two Erysiphe species, E. trifoliorum and E. pisi DC. var. pisi occur on Trifolium species. The main morphological differences between these two species are the branching of appendages and number of asci per chasmothecium. Apices of appendages mostly simple, sometimes 1-2 times dichotomously branched, longer appendages (2-6 times) and chasmothecia with 3-12 asci are characteristic for E. trifoliorum, whereas E. pisi var. pisi is characterized by having appendages $0.5-5$ times as long as chasmothecial diam., mycelioid, rarely irregularly branched and (3-)4-8(-13) asci per chasmohecium (Braun \& Cook 2012). The number of asci in 
our specimen is not significant for the identification, whereas loosely dichotomously branched appendages show that the present fungus rather belongs to a species of sect. Microsphaera. Morphologically, our specimens are similar to E. trifoliorum. ITS sequences of our specimens were completely identical to E. trifoliorum (LC009955), but 28S rRNA gene had $99 \%$ similarity to $E$. hyperici and E. euonymi (sequences of $28 \mathrm{~S}$ rRNA gene for this species are not available in GenBank). Two obtained sequences from our specimens on Trifolium and a sequence from Medicago were combined with two sequences of E. trifoliorum (LC009955, FJ378877) retrieved from GenBank. In total, the five sequences belonging to E. trifoliorum and a sequence of $E$. euonymi formed the E. trifoliorum s. lat. clade, supported by $83 / 96 \%$ BS values. Sequences of $E$. trifoliorum s. str. on Trifolium spp. formed a group of its own within the clade. A Trifolium sp. is the type host of E. trifoliorum. Thus, the fungus on Trifolium is regarded as E. trifoliorum. Many legume species were listed as hosts for E. trifoliorum and considered as species complex clade (Takamatsu et al. 2015a). Based on molecular and morphological results our specimens on Trifolium were identified as E. trifoliorum.

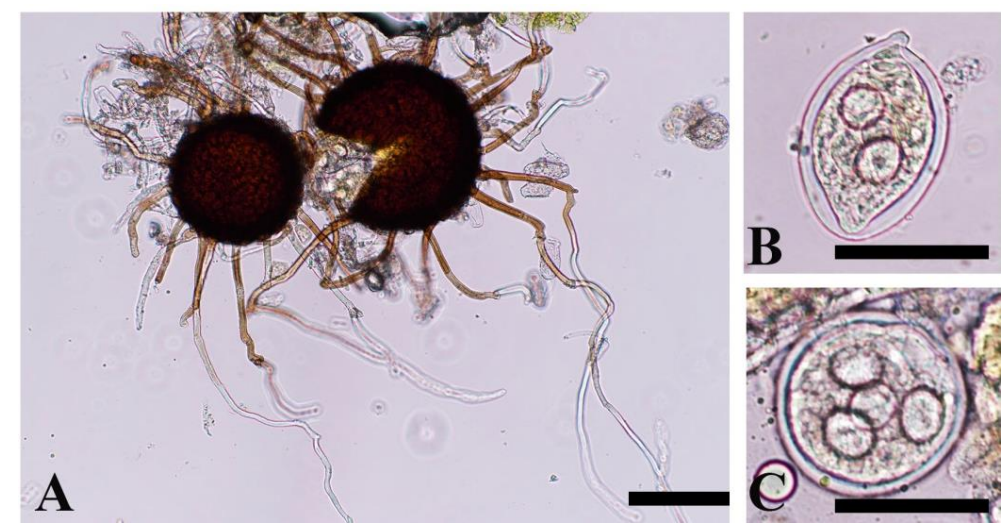

Fig. 15 - Erysiphe trifoliorum on Trifolium pratense (TSU-MUMH 7031). A Chasmothecia. B, C Asci and ascospores. Bars $=50 \mu \mathrm{m}$.

Erysiphe trifoliorum sensu lato.

Fig. 16

Description - Mycelium amphigenous, effuse, often covering the whole leaf surface, thin, persistent to evanescent. Hyphae 4-7 $\mu \mathrm{m}$ wide, hyphal appressoria lobed. Conidiophores arising from the top of mother cells or lateral, (79-)83-115(-122) $\mu \mathrm{m}$ long, foot-cells cylindrical, straight to flexuous, (28-)31-50 × 6-9 $\mu \mathrm{m}$, followed by one long cell or sometimes two shorter cells, forming conidia singly. Conidia ellipsoid, cylindrical, doliiform, (28-)30-45 × 18-22(-25) $\mu \mathrm{m}$, length/width ratio (1.4-)1.5-2.2. Germ tubes variable, terminal, long, showing longitubus pattern.

Specimen examined - On Medicago littoralis Loisel. (Fabaceae), Badamdar, Baku, N

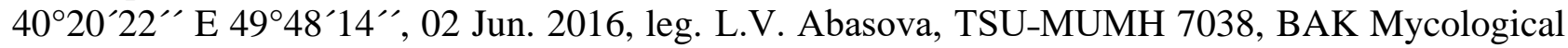
Herbarium No 10063, DDBJ ID no: LC270860 (ITS and 28S rRNA gene).

Notes - Erysiphe pisi DC. is a common powdery mildew pathogen on Medicago species worldwide. Asexual morph characteristics of our specimen are similar to the description of $E$. trifoliorum in Braun \& Cook (2012). However, the asexual morphs of E. pisi and E. trifoliorum are rather similar to one another. Mainly doliiform to ellipsoid-cylindrical conidia were observed in our specimen, whereas almost consistently ellipsoid-cylindrical conidia are characteristic for E. pisi. E. pisi has a length/width ratio of conidia of 1.6-2.5, which is similar to our specimen as well. A nucleotide sequence obtained from our specimen was $99 \%$ identical to a sequence of E. trifoliorum on Medicago sp. (FJ378877) from the USA (Attanayake et al. 2010). Molecular phylogenetic analysis showed that the sequence of the isolate from Azerbaijan on Medicago belongs to the E. trifoliorum s. lat. clade. Nucleotide similarities between isolates from Medicago and Trifolium are 99.4 and $99.2 \%$ in ITS and 28S rRNA gene regions, respectively. Based on molecular examination, specimen on $M$. sativa was identified as E. trifoliorum s. lat. 


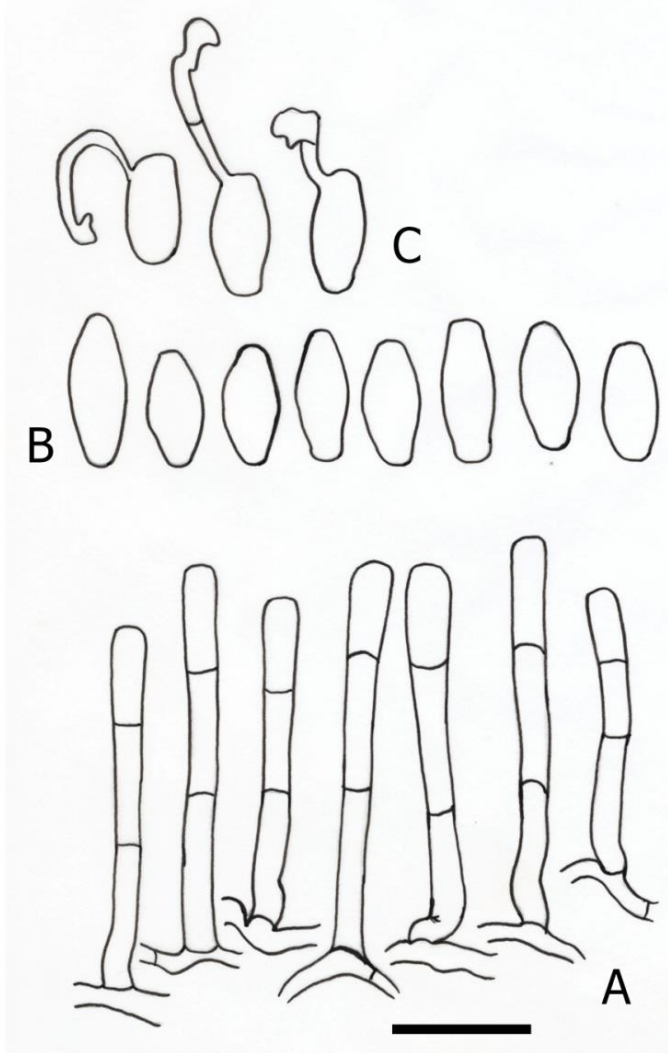

Fig. 16 - Erysiphe trifoliorum sensu lato on Medicago littoralis (TSU-MUMH 7038). A Conidiophores. B Conidia. C conidial germination. Bar $=50 \mu \mathrm{m}$.

\section{Erysiphe sect. Uncinula}

Erysiphe arcuata U. Braun, S. Takam. \& Heluta, Schlechtendalia, 16: 99, 2007.

Fig. 17

Description - Mycelium amphigenous, often epiphyllous, effuse or in irregular patches, sometimes covering the whole leaf surface, evanescent to persistent, thin, white to grayish, often conspicuous on the upper, inconspicuous on the lower leaf surface. Hyphae 4-7 $\mu \mathrm{m}$ wide, hyaline, thin-walled, smooth, hyphal appressoria lobed or nipple-shaped, solitary or in opposite pairs. Conidiophores arising centrally from top of the mother cell, erect, 60-190(-220) $\mu \mathrm{m}$ long, straight. Foot-cells cylindrical, straight to flexuous-geniculate, basal septum occasionally elevated above the mother cell, (23-)28-133 $\times 5-8 \mu \mathrm{m}$, followed by 1-2 shorter cells, or one cell about as long as foot-cell and one shorter cell, forming conidia singly. Conidia doliiform to ellipsoid-ovoid, rarely cylindrical, $27-43 \times 15-19(-21) \mu \mathrm{m}$, length/width ratio 1.6-2.5. Germ tubes terminal, short to medium in length, conidial appressoria multilobed.

Specimen examined - On Carpinus orientalis Mill. (Betulaceae), Botanical garden, Baku, 12 Sep. 2014, leg. L.V. Abasova, TSU-MUMH 7010, BAK Mycological Herbarium No 10035, DDBJ ID no: LC270840 (ITS).

Notes - Producing conidia singly and lobed hyphal appressoria determined that the present fungus belongs to an asexual morph of the genus Erysiphe. Erysiphe fimbriata S. Takam. (sect. Erysiphe), E. ellisii (U. Braun) U. Braun \& S. Takam. (sect. Microsphaera), E. arcuata, E. carpinicola (Hara) U. Braun \& S. Takam., E. carpini-cordatae (Tanda \& Y. Nomura) u. Braun \& S. Takam., E. carpini-laxiflorae U. Braun, S. Takam. \& Heluta, and E. wuyiensis (Z.X. Chen \& R.X. Gao) U. Braun \& S. Takam. (sect. Uncinula) have been described on Carpinus spp. Since the sexual morph was not developed in our sample, its allocation to one of the Erysiphe sections could not be determined. The asexual morphs of the numerous Erysiphe species are insufficiently known or unknown (Braun \& Cook 2012), which prevented an identification just based on morphology. Therefore, molecular sequence analyses were performed to allow identification. The retrieved ITS 
nucleotide sequence was identical to $E$. arcuata on $C$. betulus L. (AB252460). The size and 1/w ratio of conidia in $E$. arcuata $(25-45 \times 10-19 \mu \mathrm{m} ; 1 / \mathrm{w}=1.5-3)$ agrees well with our specimen. The foot-cells in the specimen from Azerbaijan are very long, (23-)28-133 $\mu \mathrm{m}$ long, i.e., they are much longer compared to the length of $20-50(-70) \mu \mathrm{m}$ given in Braun \& Cook (2012). However, the length of the entire conidiophores was not mentioned in the latter work. In a study published by Pastirčáková et al. (2008), the conidiophores were described to be 65-140 $\mu \mathrm{m}$ long in a specimen on $C$. betulus. Despite the difference in the length of foot-cells, the present fungus was identified as $E$. arcuata especially based on molecular results and other morphological characteristics. The length of conidiophores if often variable and can be influenced by external ecological conditions and by the host plant itself, e.g., with obvious differences between conidiophores formed on the

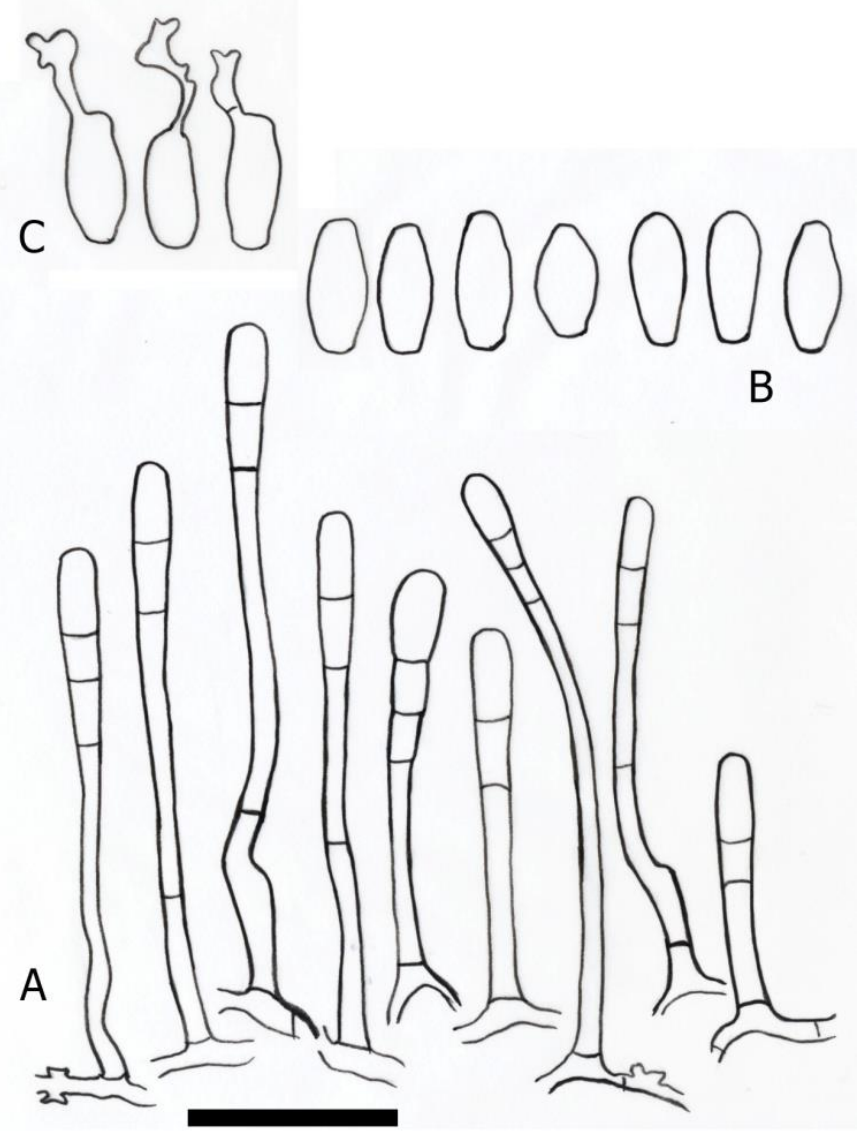

Fig. 17 - Erysiphe arcuata on Carpinus orientalis (TSU-MUMH 7010). A Conidiophores. B Conidia. $\mathrm{C}$ conidial germ tubes. Bar $=50 \mu \mathrm{m}$.

lower and upper leaf surface (Braun \& Cook 2012). Sequence data of our specimen cluster together with sequences of $E$. arcuata in the phogenetic tree, supported by $100 \%$ BS values in both MP and ML analyses (Fig. 1). Based on these results our specimen was identified as E. arcuata. This species is the first record for Azerbaijan, and C. orientalis is a new host plant for E. arcuata worldwide.

Erysiphe necator Schwein., Trans. Amer. Philos. Soc. II, 4: 270, 1834, var. necator.

Fig. 18

Description - Mycelium amphigenous, on fruits and leaves, effuse or in irregular patches, almost persistent. Chasmothecia scattered to gregarious, (77-)80-140(-156) $\mu \mathrm{m}$ diam., appendages 9-21, equatorial, flexuous, very long, (142-)190-410 $\mu \mathrm{m}$ long, 6-10 $\mu \mathrm{m}$ wide, septate, yellowish near to the base, but paler or hyaline near to the upper half, walls thin, smooth, apices loosely or tightly uncinate-circinate, not enlarged. Asci (3-)4-8, mainly 6-8, ellipsoid-ovoid, saccate, (39- 
40-66(-73) $\times \quad 28-45(-50) \mu \mathrm{m}$, sessile or short-stalked, (2-)3-6-spored. Ascospores ellipsoid-ovoid, (14-)15-24 × (8-)9-14 $\mu \mathrm{m}$, colorless.

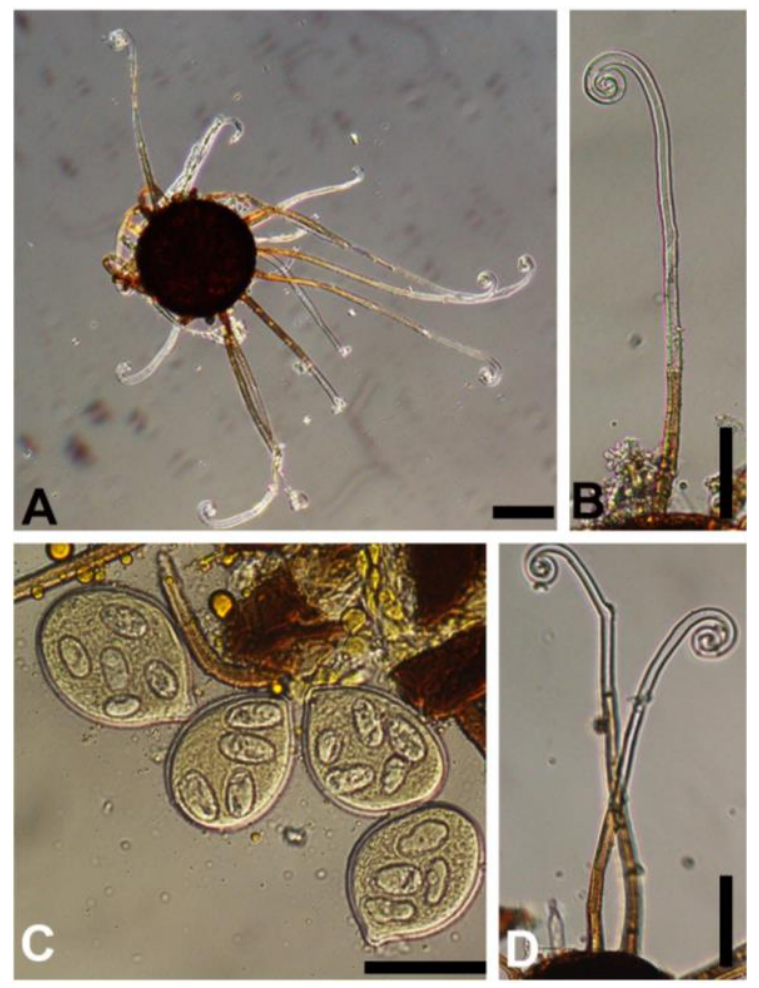

Fig. 18 - Erysiphe necator var. necator on Vitis vinifera (TSU-MUMH 7027). A Chasmothecia. B, D Appendages. C Asci and ascospores. Bars $=50 \mu \mathrm{m}$.

Specimens examined - On Vitis vinifera L. (Vitaceae), Lokbatan, Baku, N 40¹9`38' E 4043'48', 11 Nov. 2015, leg. L.V. Abasova, TSU-MUMH 7026, BAK Mycological Herbarium No 10051, DDBJ ID no: LC270853 (ITS); Lokbatan, Baku, 05 Nov. 2015, leg. L.V. Abasova, TSU-MUMH 7027, BAK Mycological Herbarium No 10052, DDBJ ID no: LC270854 (ITS).

Notes - Uncinate-circinate appendages and polyascal chasmothecia of our specimens indicated that this fungus belongs to Erysiphe sect. Uncinula. Two varieties of E. necator, viz. var. necator and var. ampelopsidis are known on Vitaceae, and only var. necator occurs on Vitis spp. worldwide. The appendages in var. ampelopsidis are shorter, 0.75-2.5 times as long as the chasmothecial diam., compared to much longer appendages in var. necator, which are 1-6 times as long as the chasmothecial diam. (Braun \& Cook 2012). Two newly determined sequences were combined with a sequence of $E$. necator retrieved from GenBank for the present phylogenetic analyses. These sequences formed a distinct monophyletic clade, which is supported by $100 \% \mathrm{BS}$ values, in both MP and ML analysis (Fig. 1). Based on morphology and molecular results our specimens were identified as E. necator var. necator.

Erysiphe prunastri DC., Fl. franç., 6: 108, 1815, var. prunastri.

Fig. 19

Description - Mycelium amphigenous, thin, effuse or in patches, evanescent to persistent. Chasmothecia scattered to gregarious, (99-)102-143(-148) $\mu \mathrm{m}$ diam., appendages dimorphic, either long and uncinuloid or short and bristle-like (anchor appendages), uncinuloid appendages (9)11-22, equatorial, stiff to flexuous, 90-150 × (4-)5-7 $\mu \mathrm{m}$, aseptate, width equal throughout, hyaline, walls smooth to rough, apices tightly uncinate to circinate, somewhat enlarged, bristle-like appendages numerous in young chasmothecia, less or almost lacking in mature ones, situated between the uncinate appendages and in the upper half, straight or sinuous, hyaline. Asci 8-16, ellipsoid-obovoid, saccate-clavate, $(36-) 39-60(-62) \times 22-33 \mu \mathrm{m}$, short-stalked or sessile, 4-8spored. Ascospores ellipsoid-ovoid, (12-)13-17 × 7-10 $\mu \mathrm{m}$, colorless. 
Specimens examined - On Prunus domestica L. (Rosaceae), Tengalti vil., Quba, N $41^{\circ} 21^{\prime} 35^{\prime \prime}$ E 48 3045”, 19 Jul. 2016, leg. L.V. Abasova, TSU-MUMH 7004, BAK Mycological Herbarium No 10029.

Notes - The morphology of the chasmothecia characterized by having appendages with circinate-uncinate tips revealed that the present fungus belongs to Erysiphe sect. Uncinula. Only one species of this section, E. prunastri, is known as powdery mildew pathogen on Prunus spp. Recently, a new variety of this species, var. japonica Meeboon \& S. Takam., has been described from Japan. This variety differs from var. prunastri in having mainly 8 asci (rarely 7) per chasmothecium, and in being geographically disjunct (Meeboon \& Takamatsu 2013). Our specimen was identified as E. prunastri var. prunastri just based on completely agreeing morphological characters, as the molecular examination failed.

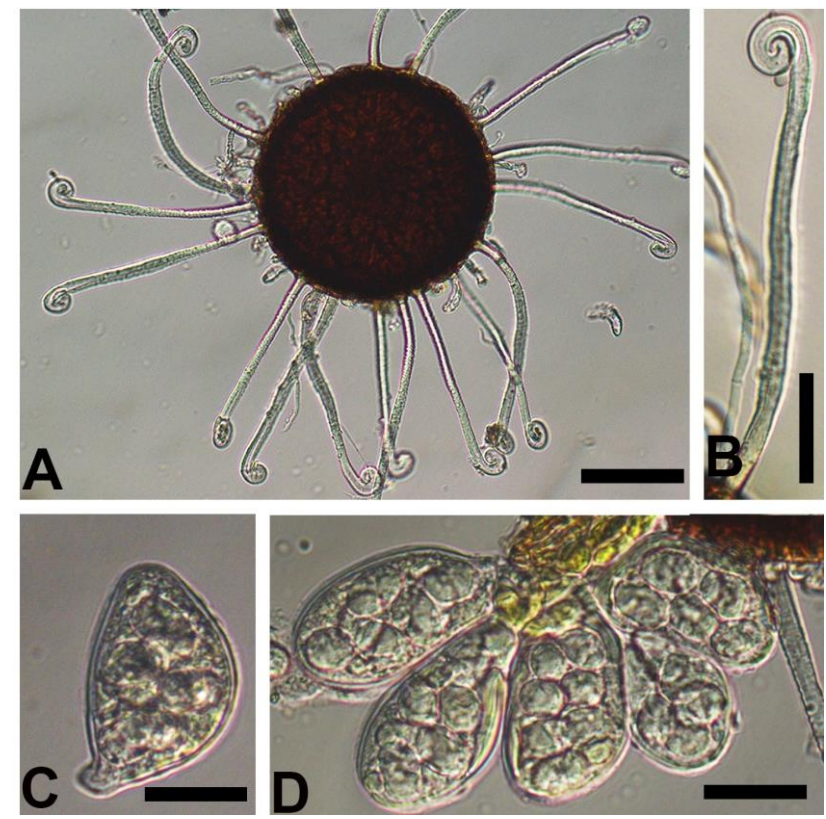

Fig. 19 - Erysiphe prunastri var. prunastri on Prunus domestica (TSU-MUMH 7004). A Chasmothecia. B Appendages. C, D Asci and ascospores. Bars $=30 \mu \mathrm{m}$.

\section{Acknowledgments}

This work was financially supported by a Grant-in-Aid for Scientific Research (No. 16K07613 and 16F16097) from the Japan Society for the Promotion of Science to ST, a grant from the Institute for Fermentation, Osaka, Japan to LA, and the Science Development Foundation under the President of the Republic of Azerbaijan - Grant No EIF-2013-9(15)-46/29/3. We are thankful to the anonymous reviewer for kindly checking the manuscript and comments.

\section{References}

Akhundov TM. 1965a - Muchnisto-rosyaniye qribi rodov Phyllactinia, Sphaerotheca, Podosphaera Nakhichevanskoy ASSR. Izvestiye Akademii Nauk Azerbaidzhanskoy SSR, seriya bioloqitcheskikh nauk 3: 24-33.

Akhundov TM. 1965b - Muchnisto-rosyaniye qribi Nakhichevanskoy ASSR (rodov Erysiphe, Uncinula). Voprosi eksprementalnoy botaniki, 155-176.

Akhundov TM. 1979 - Mikoflora Nakhichevanskoy ASSR. Izdatelstva “Elm”, Baku.

Akhundov TM, Aghayeva GB. 1978 - Nekotoriye danniye o muchno-rosyanikh gribakh Talisha. Izvestiye Akademii Nauk Azerbaidzhanskoy SSR, seriya biologicheskikh nauk 3: 3-9.

Amano K. 1986 - Host range and geographical distribution of the powdery mildew fungi. Japan Scientific Societies Press, Tokyo. 
Attanayake RN, Glawe DN, McPhee KE, Dugan FM, Chen W. 2010 - Erysiphe trifolii - a newly recognized powdery mildew pathogen of pea. Plant Pathology 59: 712-720.

Braun U, Cook RTA. 2012 - Taxonomic manual of the Erysiphales (powdery mildews). CBS Biodiversity series No. 11. CBS-KNAW Fungal Biodiversity Centre, Utrecht.

Braun U, Cook RTA, Inman AJ, Shin HD. 2002 - The taxonomy of the powdery mildew fungi. In Bélanger R., dik A.J., Bushnell W.R. (Eds.): The powdery mildews: a comprehensive treatise. APS Press, St. Paul, 13-54.

Braun U, Shishkoff N, Takamatsu S. 2001 - Phylogeny of Podosphaera sect. Sphaerotheca subsect. Magnicellulatae (Sphaerotheca fuliginea auct. s. lat.) inferred from rDNA ITS sequences - a taxonomic interpretation. Schlechtendalia 7: 45-52.

Braun U, Takamatsu S. 2000 - Phylogeny of Erysiphe, Microsphaera, Uncinula (Erysipheae) and Cystotheca, Podosphaera, Sphaerotheca (Cystotheceae) inferred from rDNA ITS sequences - some taxonomic consequences. Schlechtendalia 4: 1-33.

Braun U, Takamatsu S, Heluta V, Limkaisang S et al. 2006 - Phylogeny and taxonomy of powdery mildew fungi of Erysiphe sect. Uncinula on Carpinus species. Mycol. Progress 5(3): 139153.

Cook RTA, Braun U. 2009 - Conidial germination patterns in powdery mildews. Mycological Research 113(5): 616-636.

Cook RTA, Inman AJ, Billings C. 1997 - Identification and classification of powdery mildew anamorphs using light and scanning electron microscopy and host range data. Mycological Research 101(8): 975-1002.

Djafarov SA. 1958 - Gribi iz roda Microsphaera Lév., parazitiruyushiye na relikte tretichnoqo perioda (kashtanolistnom dube) i na kustarnikakh Talisha. Izvestiye Akademii Nauk Azerbaidzhanskoy SSR, seriya biologicheskikh i selskokhozyaystvennikh nauk 2: 11-16.

Djafarov SA. 1959 - Predstaviteli qribov roda Uncinula Lév. na derevesno-kustarnikakh porodakh Lenkoranskoy zone i nekotoriye momenti vi istorii ikh izucheniya vi Azerbaidzhane. Izvestiye Akademii Nauk Azerbaidzhanskoy SSR, seriya biologicheskikh i selskokhozyaystvennikh nauk 5: 65-71.

Edgar RC. 2004 - Muscle: multiple sequence alignment with high accuracy and high throughput. Nucleic Acids Research 32: 1792-1797.

Felsentein J. 1985 - Confidence limits on phylogenetics: an approach using the bootstrap. Evolution 39: 783-791.

Guseynov ES. 1985 - Usloviya razvitiya muchnistoy-rosi duba vi Azerbaidzhane. Izvestiya Akademii Nauk Azerbaidzhanskoy SSR, seriya bilogicheskikh nauk 3: 124-127.

Hirata T, Takamatsu S. 1996 - Nucleotide sequence diversity of rDNA internal transcribed spacers extracted from conidia and cleistothecia of several powdery mildew fungi. Mycoscience 37: 283-288.

Howe EC. 1874 - New fungi. Bulletin of the Torrey Botanical Club 5: 3-4.

Kishino H, Hasegawa M. 1989 - Evaluation of the maximum likelihood estimate of the evolutionary tree topologies from DNA sequence data, and branching order in Hominoidea. Journal of Molecular Evolution 29: 170-179.

Kljuchova MV. 1965 - Obzor muchnisto-rosyonikh qribov Absherona. Izvestiye Akademii Nauk Azerbaidzhanskoy SSR, seriya biologicheskikh nauk 3: 34-37.

Kumar S, Stecher G, Tamura K. 2016. - MEGA7: Molecular evolutionary genetics analysis version 7.0 for bigger datasets. Molecular Biology and Evolution 33(7): 1870-1874.

Meeboon J, Takamatsu S. 2013 - Erysiphe havrylenkoana and E. prunastri var. japonica: a new species and a new variety of Erysiphe sect. Uncinula (Erysiphaceae, Ascomycota). Mycological Progress 12: 277-282.

Meeboon J, Takamatsu S. 2015a - Erysiphe takamatsui, a powdery mildew of lotus: rediscovery of teleomorph after 40 years, morphology and phylogeny. Mycoscience 56: 159-167.

Meeboon J, Takamatsu S. 2015b - Notes on powdery mildews (Erysiphales) in Japan: II. Erysiphe sect. Microsphaera. Mycoscience 56: 230-236. 
Mekhtiyeva NA. 1959 - Materiali k izucheniyu mikoflori Kuba-Khachmazskoqo massiva Azerbaidzhana. Izvestiye Akademii Nauk Azerbaidzhanskoy SSR, seriya biologicheskikh i selskokhozyaystvennikh nauk 3: 19-31.

Mori Y, Sato Y, Takamatsu S. 2000 - Evolutionary analyses of the powdery mildew fungi using nucleotide sequences of the ribosomal DNA. Mycologia 92: 74-93.

Pastirčáková K, Takamatsu S, Shiroya Y, Pastirčák M. 2008 - European hornbeam powdery mildew Erysiphe arcuata in Slovakia. Journal of Phytopathology 156: 597-601.

Seko Y, Bolay L, Heluta V, Grigaliunaite B, Takamatsu S. 2008 - Molecular evidence in support of recent migration of a powdery mildew fungus on Syringa spp. into Europe from East Asia. Plant pathology 57: 243-250.

Seko Y, Heluta V, Grigaliunaite B, Takamatsu S. 2011 - Morphological and molecular characterization of two ITS groups of Erysiphe (Erysiphales) occurring on Syringa and Ligustrum (Oleaceae). Mycoscience 52: 174-182.

Sezer A, Dolar FS, Lucas SJ, Köse Ç, Günüş E. 2017 - First report of the recently introduced, destructive powdery mildew Erysiphe corylacearum on hazelnut in Turkey. Phytoparasitica 45: 577-581.

Shimodaira H, Hasegawa M. 1999 - Multiple comparisons of log-likelihood with applications to phylogenetic inference. Molecular Biology and Evolution 16: 1114-1116.

Shin HD, La YJ. 1993 - Morphology of edge lines of chained immature conidia on conidiophores in powdery mildew fungi and their taxonomic significance. Mycotaxon 66: 445-451.

Siahaan SAS, Sakamoto H, Shinoda T, Takamatsu S. 2017 - Geographic and temporal distributions of four genotypes found in Erysiphe gracilis var. gracilis, a powdery mildew of evergreen oaks (Erysiphales). Mycoscience; http://dx.doi.org/10.1016/j.myc.2017.08.002.

Silvestro D, Michalak I. 2012 - raxmlGUI: a graphical front-end for RAxML. Organisms Diversity \& Evolution 12: 335-337.

Swafford DL. 2002 - PAUP: phylogenetic analyses using parsimony (and other methods) 4.0b10. Sinauer, Sunderland, MA.

Takamatsu S, Braun U, Limkaisang S, Kom-Un S et al. 2007 - Phylogeny and taxonomy of the oak powdery mildew Erysiphe alphitoides sensu lato. Mycological Research 111: 809-826.

Takamatsu S, Hanako I, Shiroya Y, Kiss L, Heluta V. 2015a - First comprehensive phylogenetic analysis of the genus Erysiphe (Erysiphales, Erysiphaceae) I. Microsphaera lineage. Mycologia 107(3): 475-489.

Takamatsu S, Hanako I, Shiroya Y, Kiss L, Heluta V. 2015b - First comprehensive phylogenetic analysis of the genus Erysiphe (Erysiphales, Erysiphaceae) II: the Uncinula lineage. Mycologia 107(5): 903-914.

Takamatsu S, Shiroya Y, Seko Y. 2016 - Geographical and spatial distributions of two Erysiphe species occurring on lilacs (Syringa spp.). Mycoscience 57: 349-355. 